\title{
LA INTERVENCIÓN DE LA ENTIDAD PÚBLICA EN EL RÉGIMEN DE LAS RELACIONES DEL MENOR DESAMPARADO CON SU NÚCLEO AFECTIVO DE ORIGEN (ANÁLISIS DEL ARTÍCULO 161 DEL CÓDIGO CIVIL TRAS LA LEY 26/2015, DE 28 DE JULIO, DESDE LA PERSPECTIVA CONSTITUCIONAL)
}

\section{The Intervention of the Public Entity in the Regimen} of the Abandoned Child Relationships with his Affective Core of Origin (Analysis of Article 161 Civil Code after the 26/2015 Act from a Constitutional Perspective)

\author{
HELENA DÍEZ GARCÍA \\ Universidad de León \\ hdieg@unileon.es
}

Cómo citar/Citation

Díez García, H. (2016).

La intervención de la entidad pública en el régimen de las relaciones del menor desamparado con su núcleo afectivo de origen (análisis del artículo 161 del Código Civil tras la Ley 26/2015, de 28 de julio, desde la perspectiva constitucional).

Derecho Privado y Constitución, 30, 11 -74 doi: http://dx.doi.org/10.18042/cepc/dpc.30.01

(Recepción: 17/08/2016; aceptación después de la revisión: 27/09/2016; publicación: 17/1 1/2016)

\section{Resumen}

La Ley 26/2015, de 28 de julio, de modificación del sistema de protección a la infancia, ha dado nueva redacción al art. 161 CC. Ahora, la entidad pública (y no el juez) puede restringir, condicionar o suspender las relaciones del menor desamparado con su núcleo afectivo de origen; relaciones que se sustentan jurídicamente en el derecho a la vida privada y familiar, según doctrina constante del Tribunal Europeo de 
Derechos Humanos. En el presente trabajo se analiza hasta qué punto la nueva previsión legal se acomoda a la protección constitucional de estos derechos fundamentales.

\section{Palabras clave}

Protección de la infancia; interés del menor; derecho a la vida privada y familiar.

\section{Abstract}

The 26/2015 Act, of the 28th July Act, about childhood protection system modification, offers a new redaction to the art. 161 CC. Now, the Public Entity (and not the judge) can limit, restrict or suspend the abandoned child relationships with his affective core of origin; relationships that are founded legally in the right of a private and family life, according a consolidated doctrine of the European Human Rights Court. In the present work it is analyzed if the new regulation is accommodated to the constitutional protection of these human rights.

\section{Keywords}

Childhood protection; child's interest; right to a private and family life. 


\section{SUMARIO}

I. EL ART. 161 CC: UN PASO MÁS EN LA DESJUDICIALIZACIÓN DEL SISTEMA DE PROTECCIÓN DE LA INFANCIA. II. EL ART. 161 CC Y EL TRATO LEGAL DESIGUAL A MENORES, PROGENITORES, ABUELOS, HERMANOS, PARIENTES Y ALLEGADOS EN LA REGULACIÓN DE SUS RELACIONES. III. FUNDAMENTO CONSTITUCIONAL DEL DERECHO DE RELACIÓN DEL MENOR SUJETO A LA INTERVENCIÓN DE LA ENTIDAD PÚBLICA CON SUS PROGENITORES, ABUELOS, HERMANOS, PARIENTES Y ALLEGADOS: 1. Las «visitas» y el derecho a la vida privada y familiar del menor y de sus progenitores, abuelos, hermanos, parientes y allegados; 2 . El derecho a una vida en familia y el derecho a la propia familia. IV. LA LEGALIDAD DE LA INTRUSIÓN DE LA ENTIDAD PÚBLICA EN LA ESFERA PRIVADA Y FAMILIAR DEL ART. 161 CC: 1. El derecho de relación del art. 161 CC y la reserva de Ley Orgánica del art. 81.1 CE; 2. La calidad de la Ley. 3. El principio de legalidad y las injerencias públicas en la esfera de los derechos fundamentales sin autorización judicial previa. V. LAS GARANTÍAS PROCESALES DE LOS INTERESADOS EN EL PROCEDIMIENTO ANTE LA ENTIDAD PÚBLICA. VI. LA MOTIVACIÓN EN INTERÉS DEL MENOR: 1. El interés del menor en la motivación de las resoluciones que pudieran afectarle; 2 . La necesidad y proporcionalidad en la motivación en interés del menor de las resoluciones que acuerden una restricción o limitación de las relaciones del menor con su núcleo afectivo de origen. VII. BIBLIOGRAFÍA.

\section{EL ART. 161 CC: UN PASO MÁS EN LA DESJUDICIALIZACIÓN DEL SISTEMA DE PROTECCIÓN DE LA INFANCIA}

La principal novedad de este precepto, tras la Ley 26/2015, frente a la regulación anterior, además de ampliar su ámbito subjetivo de aplicación, que ahora se extiende también explícitamente a los hermanos y a los allegados, es desjudicializar el régimen de las relaciones del menor en situación de desamparo con su núcleo afectivo de procedencia, autorizándose, expresamente, a que sea la entidad pública y no la autoridad judicial, como así imponía el tenor literal anterior de ese art. $161 \mathrm{CC}$, quien pueda regular las visitas. 
No obstante, conviene advertir que no faltó alguna comunidad autónoma como Cataluña que, aun antes de esta reforma del sistema de protección a la infancia, entendió ya explícitamente en su legislación especial de protección del menor ${ }^{1}$ que la competencia para regular y, en su caso, para suspender las visitas del menor desamparado con su núcleo afectivo de origen era de la entidad pública y no del juez — suspensión de las relaciones que resulta automática cuando la entidad acuerda que la medida definitiva para el niño es su acogimiento preadoptivo -2 . Pues bien, todo apunta a que este modelo ha sido tenido en cuenta por el legislador estatal en su revisión del art. 161 CC.

En efecto, con anterioridad a esta reforma legislativa de 2015, el art. 161, en la redacción que le dio el art. 1.6 de la Ley 42/2003, de 21 de noviembre, establecía que la regulación de las relaciones entre el menor acogido con sus padres, abuelos y demás parientes, únicamente competía a la autoridad judicial ${ }^{3}$, atendidas las circunstancias y el interés del propio menor.

Sin embargo, a pesar de esa tajante declaración legal, el peculiar régimen jurídico prevenido para la constitución del acogimiento familiar provocaba ciertas distorsiones en este particular ámbito.

El esquema constitutivo del acogimiento familiar introducido por la Ley 21/1987 y que se mantuvo en la redacción del art. 173 CC tras la LO 1/1996, se estructuraba en torno a dos supuestos netamente diferenciados. Por una parte, se regulaba un acogimiento convencional con la necesaria concurrencia de una serie de consentimientos. Por otra, esta disciplina se completaba con un acogimiento judicial configurado con carácter subsidiario. La modalidad convencional se fundaba en la concurrencia de los consentimientos que, antes de la Ley 26/2015, indicaba y exigía ese mismo art. 173. Para esta forma

1 Tras la reforma de la Ley 26/2015, véase art. 68.1.III de la Ley 1/2006, de 28 de febrero, de Protección de Menores de La Rioja (redactado por el art. 48.3 de la Ley 6/2015, de 29 de diciembre, de Medidas Fiscales y Administrativas para el año 2016 de La Rioja).

2 Véase art. 116 en relación con el art. 147.3 de la Ley 14/2010, de 27 de mayo, de normas reguladoras de los derechos y las oportunidades en la infancia y la adolescencia de Cataluña. Igualmente, véase art. 24.3 del Decreto 131/20003, de 13 de noviembre, de la Junta de Castilla y León, por el que se regula la acción de protección de los menores en situación de riesgo o de desamparo y los procedimientos para la adopción y ejecución de las medidas y actuaciones para llevarla a cabo.

Pero recuérdese que, tras la reforma de la Ley 26/2015, ha desaparecido de la regulación del Código Civil, el acogimiento preadoptivo que ahora es sustituido por la denominada "guarda con fines de adopción» del art. 176 bis.

3 Véase todavía hoy el art. 86.5 de la Ley 14/2002, de 25 de julio, de promoción, atención y protección a la infancia de Castilla y León. 
de constitución del acogimiento familiar resultaba indispensable el consentimiento de los progenitores no privados de la patria potestad o del tutor no removido de su cargo. A falta de este consentimiento, la cuestión se trasladaba al ámbito judicial donde el juez debía acordar lo procedente en interés del menor a través de un procedimiento de jurisdicción voluntaria regulado, antes de la Ley 15/2015, que lo reguló temporalmente en su disposición adicional 2.4, en el art. $1828 \mathrm{LEC} / 1881$.

Pues bien, la remisión a un expediente de jurisdicción voluntaria para la constitución del acogimiento a falta de los consentimientos exigidos por el art. 173, podía reputarse en sí como contradictoria ${ }^{4}$, al tratarse de un cauce procedimental al que se recurría precisamente cuando existía oposición a una resolución de la Administración (véase. arts. 779 y 780 LEC).

Además, el recurso a este expediente, cuyos trámites eran calificados por algunos como extravagantes ${ }^{5}$, planteaba numerosos problemas procesales ${ }^{6}$ - particularmente, por la eventual concurrencia de este procedimiento de jurisdicción voluntaria con el procedimiento de oposición a las resoluciones administrativas de declaración de desamparo del art. 780 LEC- De otra parte, estos cauces procesales ampliaban y multiplicaban las posibles vías entorpecedoras u opositoras de la familia biológica a la adopción para el menor de una solución estable dilatando en el tiempo su atención adecuada.

Bien es verdad que la LO 1/1996 trató de aliviar el problema, admitiendo, a través del art. $173 \mathrm{CC}$, que la entidad pública pudiera decretar un acogimiento familiar provisional en los supuestos en los que resultaba procedente y necesaria la formalización judicial de esta medida jurídica de protección, e imposible, en consecuencia, su constitución en sede administrativa. Al suscitarse la oposición (o la ausencia de consentimiento) en el seno del correspondiente expediente, la entidad pública tan solo podía elevar al juez la propuesta del instrumento jurídico que pretendiera, aunque, mientras tanto, y esta fue la gran novedad introducida en ese precepto por la LO 1/1996, lo podía acordar en forma provisional.

Conforme a la regulación anterior a la Ley 26/2015, el documento de formalización del acogimiento familiar había ya de incluir la regulación de las relaciones del menor acogido con sus familiares y allegados [art. 173.2.3 $\mathrm{a}$ ) CC], pero, para ello, resultaba necesaria la concurrencia de los consentimien-

\footnotetext{
4 Egea i Fernández (1995: 262).

5 Véase, en ese sentido, el preámbulo de la Proposición de Ley de actualización de la legislación sobre protección a la infancia presentada por el Grupo Socialista. BOCG, Congreso, núm. 83-1, 6 de julio de 2012.

6 Sobre el particular, véase Díez García (2013: 1801-1820 y 1855-1869).
} 
tos a los que hacía referencia el art. 173.2 CC. Por tanto, en aplicación del art. 161 en su versión anterior, en el supuesto de que existiese conformidad con el acogimiento, pero no con el ius visitandi, resultaba necesario acudir al juez ${ }^{7}$.

Además, podía pensarse, de acuerdo con el antiguo tenor del art. 161, que cualquier modificación del régimen de visitas requería la correspondiente resolución judicial vetando la posibilidad de actuación al respecto de la entidad pública. Sin embargo, no cabía obviar que ese régimen podía quedar delimitado en la misma resolución administrativa por la que la entidad pública competente hubiera acordado un acogimiento de tipo provisional que antes contemplaba el art. 173.3 CC.

Por tanto, si la entidad pública podía lo más - acordar el acogimiento, aunque fuera provisional-, había de poder también lo menos, por lo que había que admitir que, de igual modo, podía restringir suprimir o suspender el régimen de visitas con carácter provisional o cautelar si se suscitaba oposición por parte de los progenitores (o del tutor) o de otros interesados en mantener su comunicación y relación con el niño. Y así fue, bajo este entendimiento, cómo algunas normas autonómicas comenzaron a autorizar a esa entidad para injerirse en la esfera de las relaciones entre el menor y su familiar de origen con un mero carácter cautelar ${ }^{8}$. Y de ello resultaba, sin perjuicio de la necesaria activación de la intervención judicial por parte del Ministerio Fiscal (art. 174) o por la misma entidad pública, que habían de ser estos interesados quienes tuvieran la carga de impugnar judicialmente esta decisión provisional por la vía del art. 780 LEC para solicitar que se modificara lo que ya podía ser una realidad?.

7 En esa hipótesis, la Fiscalía General del Estado (Consulta 8/1997, de 8 de octubre _JUR 2002, 36460_) entendía aconsejable «una práctica que ya llevan a cabo algunas entidades y que no es repudiable de forma alguna por respetar el mandato del art. 173.2 del Código Civil: hacer figurar la regulación del régimen de visitas en un documento anexo de forma que pueda modificarse posteriormente sin necesidad de renovar todo el escrito de formalización del acogimiento».

Tal y como puede apreciarse, esta práctica ha transcendido a la regulación de la formalización del acogimiento en el art. 20 LO 1/1996. El régimen de visitas no consta en la propia resolución administrativa de formalización, sino en un documento anexo.

8 Véase art. 9.2 del Decreto 42/2002, de 12 de febrero, de la Junta de Andalucía, de régimen de desamparo, tutela y guarda administrativa y art. 24.3 del Decreto 131/20003, de 13 de noviembre, de la Junta de Castilla y León, por el que se regula la acción de protección de los menores en situación de riesgo o de desamparo y los procedimientos para la adopción y ejecución de las medidas y actuaciones para llevarla a cabo.

9 Tal y como así da a entender la Circular 8/2011, de 16 de noviembre, de la Fiscalía General del Estado, 18-22. 
Este es, en parte, el entendimiento del art. $161 \mathrm{CC}$ que el Tribunal Supremo acogió ${ }^{10}$. A pesar de que en su S. 4.11 .2013 (RJ 2013, 7074) ${ }^{11}$ afirmó que «la medida de impedir la relación de la niña con su madre biológica es una medida importante en cuanto le priva del derecho que tiene a relacionarse con su familia y solo se podrá acordar para limitarla o suspenderla en casos muy excepcionales y mediante una resolución judicial fundada»; lo que impedía que la entidad pública pudiera acordarla, aun de forma cautelar, posteriormente, en la más reciente S. 18.6.2015 (RJ 2015, 2293) precisó esta interpretación y fijó doctrina legal en esta materia que ha sido acogida por la S. 3.5.2016 (RJ 2016, 2221). En su entendimiento, incluso antes de la reforma del art. $161 \mathrm{CC}$, la entidad pública sí tenía competencia para suspender las visitas y las relaciones del menor con la familia biológica. Para justificarla, consideró el Alto Tribunal que, con esta decisión, «se trata de garantizar de una forma inmediata el buen fin de la medida de protección adoptada, atendiendo a las circunstancias y al interés superior del menor en concreto, por parte de quien está facultado para adoptar la medida de separar a los hijos de sus progenitores, como es el caso del acogimiento del artículo $172.1 \mathrm{CC}$, de la que la suspensión del régimen de visitas es una simple consecuencia, quedando a salvo la función supervisora del Ministerio Fiscal y el preceptivo control judicial de la resolución administrativa adoptada por ser competencia del juez la ratificación o no de la medida mediante resolución fundada» ${ }^{12}$.

Básicamente, esta es la opción legislativa que evidencia este art. 161 tras su reforma, si bien, ahora, con el matiz de que la medida que se adopte al res-

10 Aparte de los problemas que suscitaba el art. 161 CC y que se han indicado en el texto, la regulación anterior también provocaba una relativa confusión competencial que el Tribunal de Conflictos de Jurisdicción resolvió a favor de la jurisdicción admitiendo que el juez civil, por la vía del art. 158 CC, era competente para regular las visitas del menor acogido con sus familiares. Véase SS. 4.7.2014 (RJ 2015, 1242), 10.7.2014 (RJ 2015, 1244) y 21.7.2014 (RJ 2015, 1245).

11 En igual sentido, véase SAP Granada 19.7.2013 (JUR 2014, 125997).

12 De ahí que reputara fijar como doctrina legal la siguiente: «La entidad pública está legitimada para decidir sobre la suspensión del régimen de visitas y comunicaciones de los menores bajo su tutela por ministerio legal y en acogimiento residencial respecto de sus padres biológicos, a fin de garantizar el buen fin de la medida de protección acordada, sin perjuicio de la función supervisora del Ministerio Fiscal y del preceptivo control judicial de la resolución administrativa adoptada, a quienes se dará cuenta inmediata de la medida adoptada».

Véase el comentario de esta resolución judicial en De la Iglesia Monje (2016). Igualmente, véase Pérez Conesa (2015). Asimismo, véase STSJ Galicia 26.11.2015 (RJ 2015, 6367). Para una visión crítica de esta doctrina, véase Díaz Martínez (2014. 
pecto no tiene por qué tener naturaleza provisional o cautelar sujeta a ulterior ratificación judicial. Ciertamente, la letra de ese precepto abonaría la idea de que la decisión de la entidad pública tiene tan solo un carácter cautelar al utilizar el término temporal cuando alude a la suspensión de las relaciones. Pero no es así. Y ello por una simple razón. Porque, admitida la formalización del acogimiento mediante una resolución administrativa ${ }^{13}$ por el art. 172 ter.2, así como por el art. 20.2 LO 1/1996, sea este familiar o residencial, aunque no existan los consentimientos de los que hablaba el antiguo art. 173 CC, sobra ya un acogimiento provisional y sobra también que quepa suspender las visitas con carácter cautelar, en cuanto que la entidad pública con carácter definitivo puede acordar el acogimiento mediante una resolución administrativa a la que, conforme al art. 20.3 LO 1/1993, acompaña un documento anexo donde, en su caso, se habrán regulado esas visitas. Por tanto, a los interesados (y al Ministerio Fiscal) solo les queda la vía de impugnar esa resolución administrativa por el cauce procesal del art. 780 LEC.

Se avanza, pues, y se refuerza, también en la regulación del régimen del derecho de visita y relación del niño con su núcleo afectivo de origen ${ }^{14}$, la desjudicialización ${ }^{15}$ del sistema de protección del menor ${ }^{16}$ que ya inició la LO

13 El legislador de 2015 ha sido receptivo al clamor, manifestado en los trabajos de la Comisión Especial constituida en el Senado para el Estudio de la Adopción Nacional y Otros Temas Afines, acerca de la necesidad de revisar el procedimiento de constitución del acogimiento familiar, pues era la opinión predominante la ausencia de todo sentido de que no se exigiese resolución judicial, ni, por tanto, no fuera exigido el consentimiento de los progenitores no privados de su potestad o de los tutores no removidos, para formalizar un acogimiento residencial y, en cambio, sí se requiriese para el acogimiento familiar (aunque acaso, la diferencia de trato pudiera venir dada por la apreciación del carácter irreversible, a modo de una cuasi-adopción, del acogimiento familiar). De ahí que finalmente se recomendara que en una futura regulación se admitiera expresamente la formalización en vía administrativa de cualquier clase de acogimiento, tal y como ahora cabe inferir del art. 172 ter CC (véase BOCG, Senado, núm. 545, 17 de noviembre de 2010, 9, 20, 23, 33, 39, 43, 51).

14 Durante la tramitación parlamentaria en el Congreso solo una enmienda, la enmienda 45, formulada por el Grupo Parlamentario Izquierda Plural, apostó por que el art. 173 hiciera exigible resolución judicial ante la falta de consentimiento de los progenitores o del tutor (BOCG, Congreso, núm. 131-3, 12 de mayo de 2015, 24).

15 A un sistema de administrativización total hace referencia Díaz Martínez (2014: 2). Critica esta decisión legislativa por no reputarla adecuada para la tutela del interés del menor, Cabedo Mallol (2016: 78).

16 En la justificación de la enmienda 100 al texto del proyectado art. 172.5, así como en la 227 al art. 780 LEC se realizaba la siguiente observación: «España es uno de 
1/1996, tal y como así también se recomendó desde la Comisión Especial, constituida en el Senado, para el Estudio de la Problemática de la Adopción Nacional y Otros Temas Afines (2009) ${ }^{17}$.

Ahora bien, deben también advertirse los peligros de la atribución de este omnímodo poder a la entidad pública. Este es el auténtico riesgo, siempre que no se adopten las cautelas oportunas, pues la sola vigilancia del Ministerio Fiscal ex art. $174 \mathrm{CC}$ parece resultar insuficiente ${ }^{18}$, como la práctica ha tenido la oportunidad de demostrar ${ }^{19}$.

A nadie se le oculta, dado que parecen estar en juego derechos fundamentales de los implicados en esas relaciones, que puede resultar cuestionable hasta qué punto o en qué medida una autoridad administrativa puede injerirse en la esfera de tales derechos e intereses. Pero, antes de ofrecer una solución irreflexiva

los pocos países del mundo en que las decisiones en materia de protección como la declaración de desamparo, el acogimiento familiar o residencial no son adoptadas por una autoridad judicial. El proceso previsto en este artículo es la única vía para instar la revisión judicial de estas decisiones. Para garantizar que todas estas decisiones son adoptadas desde el más escrupuloso respeto a la plena realización y ejercicio de los derechos de los niños y las niñas, es esencial que estos procesos sean accesibles a todas las personas legitimadas para el inicio de estas acciones, incluidos los propios menores afectados. Sólo si estos procesos reúnen todas estas garantías y resultan plenamente accesibles a las personas afectadas, es aceptable la falta de autorización judicial para la adopción de estas decisiones» (BOCG, Congreso, núm. 131-3, 12 de mayo de 2015, pág. 62 y págs. 142-143).

17 BOCG, Senado, núm. 545, 17 de noviembre de 2010, 52-53. Recomendación 53.

18 La Proposición de Ley del Grupo Socialista de Ley de actualización de la legislación sobre protección de la infancia (BOCG, Congreso, núm. 83-1, 6 de julio de 2012) acogía igualmente la recomendación de esa Comisión Especial y el apartado 2 de su artículo 6 preveía también la modificación del art. 161 CC en idéntico sentido; esto es, desjudicializando a favor de la entidad pública la regulación de las visitas. Sin embargo, y diferencia de la redacción actual de este precepto, se preveía un párrafo segundo con el siguiente tenor: «La resolución administrativa que suspenda temporalmente el derecho de visitas deberá estar debidamente motivada y habrá de ser notificada al afectado, pudiendo ser judicialmente impugnable conforme a lo previsto en el artículo 780 de la Ley de Enjuiciamiento Civil».

19 El Defensor del Pueblo (2014: 28-29) ponía de manifiesto que la Fiscalía, por lo general, no dispone de medios ni de recursos necesarios, para poder supervisar la situación del menor y la actuación de la entidad pública. Rara vez la Fiscalía manifiesta su disconformidad con la entidad pública. Como explica la misma Fiscalía General del Estado, en su Memoria de 2013, el número total de impugnaciones formuladas por el Fiscal resulta escasa (10) frente al número de las que presentaron los particulares (1450) (Fiscalía General del Estado, 2013: 432). 
o precipitada, resulta preciso analizar en profundidad los eventuales derechos e intereses que pueden verse implicados y afectados por semejante intrusión del poder público para luego delimitar si esa injerencia puede o no constitucionalmente admitirse y, en su caso, en qué condiciones o con qué requisitos esta intromisión resulta autorizada. Sin embargo, como paso previo a ese análisis, resulta conveniente analizar la diferencia de trato que el legislador otorga a los menores en su relación con sus familiares y allegados y, a su vez, a estos.

\section{EL ART. 161 CC Y EL TRATO LEGAL DESIGUAL A MENORES, PROGENITORES, ABUELOS, HERMANOS, PARIENTES $Y$ ALLEGADOS EN LA REGULACIÓN DE SUS RELACIONES}

Una lectura comparada del tenor del contenido de este art. 161 CC, antes y después de la reforma de 2015, permite apreciar dos diferencias fundamentales en su tenor.

En primer lugar, tal y como se ha indicado, la autoridad judicial se ha visto sustituida por la entidad pública para regular las relaciones a las que este art. 161 hace referencia. En segundo lugar, la letra actual de este precepto y a diferencia de lo que predicaba con anterioridad a la Ley 26/2015, concede dicha competencia a esa entidad pública, pero únicamente respecto a menores en situación de desamparo frente al más amplio concepto de «menor acogido» que utilizaba su precedente. Y puesto que el acogimiento era y es una forma de ejercicio de la guarda, ese menor podía (y puede) ser tanto un menor sujeto a la tutela ex lege como un menor afecto a la mera guarda, de acuerdo con la dicción del art. 172.3 CC en su redacción anterior a la reforma de 2015 y conforme al actual art. 172 ter. 1 CC.

Ahora, por tanto, el art. 161 acota el ámbito subjetivo de aplicación y tan solo menciona a los menores en situación de desamparo omitiendo realizar cualquier referencia a los menores sujetos solo a la guarda de la entidad pública $e x$ art. 172 bis CC y ex art. 19 LO 1/1996, aunque estos, al igual que aquellos, pueden estar afectos a un acogimiento familiar o residencial (art. 172 ter.1 CC).

Quizá esta omisión resulte imputable únicamente a un descuido o a un olvido del legislador. Pero, dado que su aplicación puede ocasionar una aflicción de los derechos fundamentales de los implicados en esas relaciones, tal y como se tendrá la oportunidad de detallar más adelante y, puesto que ese art. 161 CC resulta claramente una excepción a la regla general del art. 160 CC, que exige la intervención de la autoridad judicial para regularlas, se impone una interpretación restrictiva del precepto, por lo que se ha de entender que respecto a los menores acogidos sujetos solo a la guarda de la entidad pública, 
únicamente la autoridad judicial puede limitar y, en su caso, suspender, las relaciones del menor con su núcleo afectivo de procedencia.

De otra parte, cuando se trate de un menor en acogimiento residencial en un centro de protección específico para solventar sus trastornos de conducta (arts. 25 a 35 LO 1/1996), ya no es ni tan siquiera la entidad pública la llamada a regular las relaciones de ese menor con sus familiares y allegados, sino que es el director del centro donde hubiera sido ingresado ese menor (arts. 35 y 36 LO 1/1996) quien resulta legitimado para fijar el régimen de visitas y de comunicaciones.

Como puede apreciarse, se vislumbra un trato legislativo diferenciado entre los menores que pueden verse sujetos a un acogimiento familiar o residencial, tanto en función de que estén sujetos a la tutela de una entidad pública o solo lo estén a su guarda o de que estén afectos a un especialísimo acogimiento residencial aun cuando esa entidad no tenga ni su tutela ni su guarda ${ }^{20}$. Pero también esa diferencia se aprecia entre estos menores y aquellos que no están sujetos a ninguna medida de protección.

En efecto, aunque el art. 160 CC no se pronuncia expresamente sobre este extremo, su redacción permite entender -obsérvese que este precepto equipara a la entidad pública con la autoridad judicial en la restricción de las visitas, pero solo para los casos previstos en el art. 161 que se refiere específicamente, como se ha visto, a menores desamparados- que, para los menores no afectos a la intervención administrativa en función de su situación de desamparo, sus relaciones con sus progenitores y otros familiares y allegados solo pueden ser limitadas o suspendidas por una decisión judicial.

Abunda en esta conclusión el veto a la posibilidad de eludir la necesaria homologación judicial de los convenios reguladores de la nulidad, separación

20 De acuerdo con el art. 25.1, párrafo segundo de la LO 1/1996, estos centros de protección especial de menores con trastornos de conducta están destinados «al acogimiento residencial de menores que estén en situación de guarda o tutela de la entidad pública». Sin embargo, el art. 26.1 LO 1/1996 concede legitimación para recabar la preceptiva autorización judicial (art. 778 bis LEC) tanto a la entidad pública, tenga la tutela o la guarda del menor, cuanto al Ministerio Fiscal. Tampoco cabe desconocer que el juez, ex art. 158 CC, de oficio, o a instancia de parte interesada, pueda adoptar las medidas oportunas a fin de apartar al menor de un peligro o de evitarle perjuicios en su entorno familiar o frente a terceras personas, por lo que, aparte de poder decretar, por ejemplo, que la guarda sea asumida por la entidad pública, podría confiar esa guarda a una persona o institución idónea (véase art. 103 CC). Por eso mismo, directamente podría autorizar el ingreso del menor en uno de estos centros. Y, por este motivo, hipotéticamente, cabría pensar que esos menores en régimen de acogimiento residencial no necesariamente habrían de estar sujetos a la tutela o a la guarda de la entidad pública. 
o divorcio a los que hace alusión el art. $90 \mathrm{CC}^{21}$ cuando existan hijos menores de edad y al no admitirse, tras la reforma efectuada por la Ley 15/2015, que la disolución del vínculo matrimonial o la separación conyugal pueda realizarse extrajudicialmente en presencia de tales hijos menores ${ }^{22}$. Y, obsérvese, tanto la entidad pública como los progenitores son titulares de una potestad que han de ejercitar en interés de los menores a su cargo. Por tanto, se vislumbra también un trato legal desigual entre los progenitores en función de que sus hijos menores hayan sido o no declarados en desamparo o hayan o no sido afectos al acogimiento residencial de los arts. 25 a 35 LO 1/1996, pero también se evidencia un trato diferenciado entre los titulares de la patria potestad y esa entidad como tutora de los menores.

Ahora bien, hay que partir, no obstante ese trato legal evidentemente desigual, de que no toda diferenciación supone una discriminación proscrita, pues es necesario que personas situadas en situaciones análogas o comparables gocen de un trato preferente y que esta diferencia resulte discriminatoria ${ }^{23}$. De este modo, tal y como así entiende el TEDH, «una distinción es discriminatoria en el sentido del art. $14^{24}$ si carece de «justificación objetiva y razonable»; es decir, si no responde a un «objetivo legítimo»" ${ }^{25}$ si no hay «una relación

21 Precisamente, para evitar cualquier atisbo de discriminación entre los hijos, los arts. 748 y 777 LEC deben aplicarse a los supuestos en que pretenda homologarse un convenio regulador de la ruptura de una unión extramatrimonial, tal y como así entendió expresamente el AAP Valencia 23.10.2002 (JUR 2003, 52919). En igual sentido, véanse por ejemplo, SAP Córdoba de 17.7.1998 (AC 1998, 6125) y SAP Barcelona 22.4.2003 (JUR 2003, 254191).

De ahí que se exija, incluso en las uniones extramatrimoniales, que el correspondiente convenio regulador de la ruptura sea sometido al control tanto del Ministerio Fiscal como de la autoridad judicial cuando afecte a «derechos-deberes irrenunciables de patria potestad, guarda y custodia, derecho de visitas y alimentos» [véase STS 11.7.2002 (RJ 2002, 7144). Igualmente, véase AAP Barcelona 8.4.1999 (AC 1999, 885)].

22 Sobre el particular, véase Díaz Martínez (2016: 196 y ss.).

23 SSTEDH 11.6.2002 —asunto Willis contra Reino Unido- (TEDH 2002,36); 16.11.2004 —asunto Ünal Tekeli contra Turquía- (TEDH 2004, 88); 9.11.2010 —asunto Losonci Rose et Rose contra Suiza- (JUR 2010,367175); 17.2.2011 —asunto Andrle contra República Checa- (TEDH 2011, 23); 7.1.2014 —asunto Cusan y Fazzo contra Italia- (TEDH 2014, 2). Art. $14 \mathrm{CEDH}$.

25 Por ejemplo, la suspensión de los derechos de visita de un progenitor a su hijo menor motivada exclusivamente en sus propias convicciones religiosas, puede llegar a suponer «una diferencia de trato entre el demandante y otros padres en una situación análoga, que consistió en reprochar al demandante por sus profundas convicciones 
razonable de proporcionalidad ${ }^{26}$ entre los medios empleados y el fin persegui$\mathrm{do}^{27}$. Por tanto, existe únicamente discriminación cuando se trata de manera diferente o de modo menos favorable ${ }^{28}$ «sin justificación objetiva y razonable a personas que se encuentran en situaciones comparables ${ }^{29}$.

En similar sentido se manifiesta el Tribunal Constitucional ${ }^{30}$. En su criterio, lo que prohíbe el principio de igualdad son las desigualdades que resulten

religiosas» [STEDH 12.2.2013 —asunto Vojnity contra Hungría- (TEDH 2013, 18)].

26 SSTEDH 8.7.1986 —asunto Lithgow y otros contra Reino Unido- (TEDH 1986, 72); 1.2.1997 —asunto Van Raalte contra Países Bajos- (TEDH 1997, 11); 12.2.20013 — asunto Vojnity contra Hungría— (TEDH 2013, 18).

27 SSTEDH 23.10.1990 — asunto Darby contra Suecia— (TEDH 1990, 26); 23.6.1993 —asunto Hoffmann contra Austria- (TEDH 1993, 27); 24.2.1995 — asunto McMichael contra Reino Unido- (TEDH 1995, 9); 1.2.2000 —asunto Mazurek contra Francia- (TEDH 2000, 45); 26.2.2002 — asunto Fretté contra Francia(TEDH 2002, 10); 8.7.2003 — asunto Sommerfeld contra Alemania- (JUR 2003, 162887); 3.12.2009 —asunto Zaunegger contra Alemania- (JUR 2009, 473440); 17.2.2011 —asunto Andrle contra Republica Checa- (TEDH 2011, 23); 7.2.2013 —asunto Fabris contra Francia- (JUR 2013, 35557); 3.4.2014 —asunto Konstantinidis contra Grecia- (JUR 2014, 101417); 1.7.2014 — asunto Ruszkowska contra Polonia- (TEDH 2014, 46); 23.2.2016 —asunto Pajic contra Croacia- (TEDH 2016,8).

28 SSTEDH 7.11.2013 —asunto Vallanatos y otros contra Grecia- (JUR 2013, 343829); 23.2.2016 —asunto Pajic contra Croacia- (TEDH 2016, 8).

29 Véanse así, entre otras muchas, SSTEDH 11.6.2002 —asunto Willis contra Reino Unido (TEDH 2002, 36); 26.2.2002 —asunto Fretté contra Francia- (TEDH 2002, 10); 8.7.2003 — asunto Sommerfeld contra Alemania- (JUR 2003, 162887); 16.11.2004 —asunto Ünal Tekeli contra Turquía - (TEDH 2004, 88); 12.12 .2006 —asunto Burden y Burden contra Reino Unido- (TEDH 2006, 76); 3.12.2009 —asunto Zaunegger contra Alemania- (JUR 2009, 473440); 17.2.2011 —asunto Andrle contra República Checa- (TEDH 2011, 23); 29.1.2013 —asunto Horvath y Kiss contra Hungría (TEDH 2013, 15); 7.2.2013 —asunto Fabris contra Francia- (JUR 2013, 35557); 12.2.20013 — asunto Vojnity contra Hungría- (TEDH 2013, 18); 19.2.2013 — asunto X et autres contra Austria- (JUR 2013, 53791); 7.1.2014 —asunto Cusan y Fazzo contra Italia- (TEDH 2014, 2); 3.4.2014 —asunto Konstantinidis contra Grecia - (JUR 2014, 101417); 27.5.2014 —asunto Buchs contra Suiza - (JUR 2014, 161780); 1.7.2014 — asunto Ruszkowska contra Polonia- (TEDH 2014, 46); 23.2.2016 — asunto Pajic contra Croacia- (TEDH 2016, 8).

30 Así, ha venido considerando que el art. 14 CE «impone al legislador el deber de dispensar un mismo tratamiento a quienes se encuentran en situaciones jurídicas iguales, 
artificiosas o injustificadas ${ }^{31}$ por no venir fundadas en criterios objetivos y razonables ${ }^{32}$ según juicios de valor generalmente aceptados, «por lo que para que sea constitucionalmente lícita la diferencia de trato, las consecuencias jurídicas que se deriven de tal distinción deben ser proporcionadas a la finalidad perseguida, de suerte que se eviten resultados excesivamente gravosos o desmedidos ${ }^{33}$ ». Por tanto, conforme a una doctrina constante del máximo intérprete constitucional, las diferenciaciones normativas resultarán atentas al art. $14 \mathrm{CE}$ si responden a un fin discernible y legítimo y si se articulan en términos no inconsistentes y proporcionados con la finalidad perseguida ${ }^{34}$.

Pues bien, en línea de principio, aplicando estos criterios a los supuestos legalmente desiguales en los que se encuentran los menores respecto al régimen jurídico de sus relaciones con familiares y allegados y en las que estos, a su vez, se hallan, cabría afirmar que su respectiva situación fácticamente diferenciada resulta ya de por sí bastante para justificar un trato normativo distinto.

En efecto, las circunstancias de hecho que rodean al menor desamparado y que permiten a la entidad pública asumir su tutela, o la especialísima situación que envuelve al menor con trastornos de conducta que ampara su acogimiento residencial en centros específicos y, en esa medida también, las que afectan a los posibles interesados en mantener su relación con él, son

con prohibición de toda desigualdad que, desde el punto de vista de la finalidad de la norma cuestionada, carezca de justificación objetiva y razonable o resulte desproporcionada en relación con dicha justificación [SSTC 39/2002, de 14 de febrero (RTC 2002, 39) y 69/2007 de 16 abril (RTC 2007, 69)].

31 Sin embargo, "el tratamiento diverso de situaciones distintas puede incluso venir exigido, en un Estado social y democrático de Derecho, para la efectividad de los valores que la Constitución consagra con el carácter de superiores del ordenamiento» [SSTC 34/1981, de 10 de noviembre (RTC 1981, 34); 3/1983, de 25 de enero (RTC 1983, 3); 128/1987 de 16 julio (RTC 1987, 128)].

32 Véase STC 200/2001 de 4 octubre (RTC 2001, 200).

33 A título ilustrativo, véanse SSTC 76/1990, de 26 de abril (RTC 1990, 76); 214/1994, de 14 de julio (RTC 1994, 214); 46/1999, de 22 de marzo (RTC 1999, 46); 1/2001 de 15 enero (RTC 2001, 1); 200/2001, de 4 de octubre (RTC 2001, 200); 39/2002, de 14 de febrero (RTC 2002, 39); 96/2002, de 25 de abril (RTC 2002, 96); 152/2003, de 17 de julio (RTC 2003, 152); 193/2004, de 4 de noviembre (RTC 2004, 193); 255/2004, de 23 de diciembre (RTC 2004, 255); 10/2005, de 20 de enero (RTC 2005, 10); 57/2005, de 14 de marzo (RTC 2005, 57); 54/2006, de 27 de febrero (RTC 2006, 54); 295/2006, de 11 de octubre (RTC 2006, 295) y 171/2012 de 4 octubre (RTC 2012\171).

34 Véase STC 222/1992, de 11 de diciembre (RTC 1992, 222). 
totalmente diferentes entre sí y, además, no resultan comparables con las de cualesquiera otros menores no sujetos a medida de protección alguna o con las de aquellos que solo se han visto sujetos a una medida de intervención mínima como es la asunción de la mera guarda administrativa, aunque ello suponga su alejamiento de la familia de origen con carácter temporal (art. 172 bis CC y 19 LO 1/1996). De este modo, dado que los términos de comparación no resultan homogéneos, no existiría discriminación alguna proscrita por el art. $14 \mathrm{CE}$ (o por el art. $14 \mathrm{CEDH}$ ), por el hecho de que se dispense un trato legal diferenciado en la regulación de las relaciones del menor con sus progenitores, abuelos, hermanos, parientes o allegados en función de tales variables.

Asimismo, siempre resultaría posible argumentar que el eventual trato diferente obedece a un fin que puede reputarse legítimo, cual es, proteger o tutelar el interés del menor ${ }^{35}$ (art. 2 LO 1/1996) en orden a asegurar el buen fin de la medida adoptada cuando se apreció la situación de desamparo y/o se acordó su acogimiento. Sin embargo, quizá esta no sea una justificación ni bastante, ni suficiente, pues, para asegurar la adecuada ejecución de las medidas de protección acaso resulten suficientes las previsiones del art. 216 CC; lo que permitiría a la entidad pública instar el auxilio judicial, directamente o a través del Ministerio Fiscal, para vencer tales dificultades o resistencias ${ }^{36}$, sin

35 Véanse SSTEDH 23.6.1993 —asunto Hoffmann contra Austria- (TEDH 1993, 27); 8.7.2003 — asunto Sommerfeld contra Alemania- (JUR 2003, 162887). Un trato desigual por razón de la edad, puede responder así a una finalidad constitucionalmente legítima, como puede ser proteger al menor [véase STC 55/1994, de 24 febrero (RTC 1994, 55)].

36 Así no faltan las normas automáticas que prevén que la entidad pública solicite el auxilio judicial cuando existen dificultades para ejecutar la medida de protección. Por ejemplo, el art. 63 de la Ley 3/2005, de 18 de febrero, de atención y protección a la infancia y la adolescencia del País Vasco, contiene la previsión, para el caso de que concurriese alguna circunstancia que obstruyese la ejecución de las medidas acordadas en caso de desamparo de un menor, que la entidad pública solicite del Ministerio Fiscal la adopción, con la mayor celeridad posible, «de las medidas precisas para hacerlas efectivas, sin perjuicio de las intervenciones inmediatas que fuesen necesarias si estuviera en peligro la vida o integridad de la persona menor de edad o se estuvieran conculcando sus derechos». Evidentemente, hay que leer dicha previsión como una referencia implícita al art. 216 CC.

Igualmente, véase art. 50 de la Ley 1/1997, de 7 de febrero, de normas reguladoras de la atención integral a los menores de Canarias; art. 71 de la Ley 8/2010, de 23 de diciembre, de garantía de derechos y atención a la infancia y la adolescencia de Cantabria; art. 74 de la Ley 14/2002, de 25 de julio, de promoción, atención y protección a 
perjuicio de adoptar cualquier decisión cautelar si razones de urgencia así lo aconsejan sujeta a una ulterior ratificación judicial.

De otra parte, también sería posible pensar que, en estos casos, la entidad pública, en cuanto tutora de estos menores, se erigiría por el legislador en garante bastante de su interés en la regulación de estas relaciones, lo que justificaría el que pudiera sustituir a la autoridad judicial en tales casos.

Sin embargo, hay que tener presente que el título de atribución que permite a la entidad pública intervenir en la esfera de los menores desamparados y que deriva de la declaración legal contenida en los arts. 172.1 CC y 18 LO 1/1996, es la tutela. Cabe pensar entonces que, resultando titular de una potestad familiar o cuasi-familiar que, obviamente, ha de ejercitar en interés del pupilo como cualquier otro tutor, su posición en poco o nada diferiría de los titulares de la patria potestad o de los tutores ordinarios. Y, como es conocido, ninguno de ellos puede por sí injerirse de la forma en que lo puede hacer la entidad pública en la esfera de las relaciones de sus hijos y tutelados menores de edad, a pesar de que ambos resultan obligados a ejercer su oficio en beneficio del hijo o del pupilo menor, como así les exige el art. $154 \mathrm{CC}$ o el art. 268 CC o el mismo art. 2 LO 1/1996. Además, también cabe afirmar que no cabe ser juez y parte al mismo tiempo. Y, por ello, el art. $174 \mathrm{CC}$ a quien atribuye la "superior vigilancia» de la tutela, del acogimiento o de la guarda de los menores, es al Ministerio Fiscal, lo que también se cohonesta con lo dispuesto en el art. 233 CC. En esa medida, también se apreciaría el desigual trato dispensado por el legislador entre estos titulares de potestades familiares, pues, como se ha indicado, ni siquiera los titulares de la patria potestad pueden autorregular eficazmente el régimen de las relaciones de sus hijos menores sin la intervención judicial.

No obstante, y al margen de estas consideraciones, el fin perseguido por el art. 161 CC que puede considerarse legítimo, quizá resulte desproporcionado al agravar la situación de los menores y de los interesados en mantener su relación respecto a lo que sucedería de no mediar la intervención de la entidad pública ex art. 172.1 CC o en el supuesto de que el menor no fuera ingresado en un centro de la clase a la que se refiere el art. 25 LO 1/1996.

la infancia de Castilla y León; art. 72 de la Ley 17/2006, de 13 de noviembre, integral de la atención y de los derechos de la infancia y la adolescencia de las Islas Baleares; art. 42 de la LF 15/2005, de 5 de diciembre, de promoción, atención y protección a la infancia y la adolescencia de Navarra; art. 20 de la Ley 1/1995, de 27 de enero, de protección del menor de Asturias. 
Ciertamente, siempre cabría argumentar que, precisamente estos menores tutelados por la entidad pública (o afectos al acogimiento residencial de los art. 25 a 35 LO 1/1996), necesitan de una mayor tutela o protección que cualesquiera otros, en función, precisamente, de la privación de la asistencia moral y/o material de la que hablan los arts. 172.1 CC y 18 LO 1/1996 o por causa del trastorno social al que se refiere el art. 25 LO 1/1996, por lo que habría que exigirse un plus a dicha tutela jurídica. Pero esto es justamente lo contrario de lo que parece deducirse de este art. 161 CC.

Quizá nos encontremos, pues, en el caso de este precepto, ante una discriminación encubierta o indirecta ${ }^{37}$. Si el art. 160 CC únicamente permite restringir o suprimir la relación de los menores con sus familiares y allegados si no es en virtud de una resolución judicial, seguramente lo hace porque el legislador entiende que dicha limitación o dicha privación puede incidir en la esfera de bienes o derechos fundamentales de los diversos interesados en dichas relaciones y, especialmente, en la esfera de su intimidad personal y familiar. Y, quizá, aquí, deban entrar en aplicación las cautelas previstas en el art. $18 \mathrm{CE}$. Y siendo así, solo razones excepcionales y de peso permitirían sustraer al conocimiento de la autoridad judicial una eventual restricción o limitación de estos derechos, por lo que, en su ausencia, la injerencia administrativa no solo determinaría su conculcación, sino también, seguramente, implicaría un trato desigual en su ejercicio. Por este motivo, resulta entonces obligado examinar en profundidad en qué medida los derechos del art. 18 $\mathrm{CE}$ o que consagra el art. $8 \mathrm{CEDH}$ resultan comprometidos cuando el poder público se injiere en su libre ejercicio y en qué supuestos esta intrusión resulta autorizada cuando de lo que se trata es de restringir, limitar, condicionar o suspender las relaciones del menor con sus progenitores, abuelos, hermanos, parientes o allegados.

37 El Tribunal Constitucional reputa el art. 14 CE y prohíbe también la discriminación «encubierta o indirecta consistente en aquel tratamiento formal o aparentemente neutro o no discriminatorio del que se deriva, por las diversas circunstancias de hecho concurrentes en el caso, un impacto adverso sobre la persona objeto de la práctica o conducta constitucionalmente censurable en cuanto la medida que produce el efecto adverso carece de justificación al no fundarse en una exigencia objetiva e indispensable para la consecución de un objetivo legítimo o no resultar idónea para el logro de tal objetivo [SSTC 13/2001, de 29 de enero (RTC 2001, 13); 253/2004, de 22 de diciembre (RTC 2004, 253); 69/2007 de 16 abril (RTC 2007, 69)] 


\section{FUNDAMENTO CONSTITUCIONAL DEL DERECHO DE RELACIÓN DEL MENOR SUJETO A LA INTERVENCIÓN DE LA ENTIDAD PÚBLICA CON SUS PROGENITORES, ABUELOS, HERMANOS, PARIENTES Y ALLEGADOS}

\section{LAS «VISITAS»Y EL DERECHO A LA VIDA PRIVADA Y FAMILIAR DEL MENOR Y DE SUS PROGENITORES, ABUELOS, HERMANOS, PARIENTES Y ALLEGADOS}

El art. 160 CC también se ha visto afectado por el alcance de la reforma legislativa efectuada por la Ley 26/2015 ${ }^{38}$. El apartado 1 de este precepto reconoce el derecho de los hijos menores «a relacionarse con sus progenitores aunque estos no ejerzan la patria potestad ${ }^{39}$, salvo que se disponga otra cosa por resolución judicial o por la entidad pública en los casos establecidos en el artículo 161».

La nueva redacción de este art. 160 CC supone un giro completo en el modo de entender estas relaciones, pues ya no es solo un derecho de los padres el relacionarse con sus hijos menores, tal y como así establecía la redacción pretérita de este precepto, sino que es un derecho que se reconoce y se atribuye a los propios menores ${ }^{40}$. Este cambio resulta, pues, significativo, en cuanto que expresa una nueva óptica desde la que fundamentar jurídicamente esas relaciones que acomoda nuestro derecho interno al texto de los instrumentos jurídicos internacionales en materia de reconocimiento de derechos al niño ${ }^{41}$, pero también evidencia que, quizás ahora más claramente, el contenido del nuevo art. 160 CC y, en esa medida, del art. $161 \mathrm{CC}$, desborda el estricto ámbito de las relaciones paterno-filiales donde ambos preceptos se insertan ${ }^{42}$.

38 En efecto, este precepto debe su nueva redacción al art. 2.10 de la Ley 26/2015, de 28 de julio.

39 Obvio es que los progenitores cuyos hijos han sido declarados en situación de desamparo no ejercen la patria potestad, dado que la asunción de la tutela por la entidad pública comporta la suspensión de dicha potestad sobre el menor, de acuerdo con el párrafo tercero del art. 172.1 CC.

40 Véase el art. 60 del Código de Derecho Foral de Aragón y el art. 38 de la Ley 14/2010, de 27 de mayo, de normas reguladoras de los derechos y las oportunidades en la infancia y la adolescencia de Cataluña.

41 Véase el art. 9.3 de la Convención de los Derechos del Niño, el art. 14 de la Carta Europea de los Derechos del Niño (DOUE, C 241, de 21 de septiembre de 1992) y el art. 24.3 de la Carta Europea de Derechos Fundamentales.

42 Ya con el antiguo tenor del art. 160 CC resultaba difícil incardinar el derecho de relación en el contenido de la patria potestad, en cuanto que ese mismo derecho de 
Parece, pues, evidente que el derecho de visita más que un derecho de los progenitores, de los parientes o de los allegados es concebido como un derecho del propio menor que se relaciona también con su derecho a la vida familiar, con su derecho a crecer y ser educado en el ámbito de su propia familia $y$, en definitiva, con su derecho al libre desarrollo de su personalidad ${ }^{43}$ para el que pueden resultar necesarios los contactos con otras personas distintas a sus progenitores o a sus guardadores legales y cuya activación por el propio menor resulta factible a partir de lo dispuesto en el art. $158 \mathrm{CC}$ (o del art. $216 \mathrm{CC})^{44}$. Engarzado de esta forma este derecho del menor a la vida familiar en el ámbito del art. $18 \mathrm{CE}$ y, en última instancia, en el art. $10 \mathrm{CE}^{45}$, su contenido comprende otros lazos «familiares» de hecho distintos a los matrimoniales o a los estrictamente paterno-filiales, bastando, pues, la mera existencia de vínculos personales estrechos ${ }^{46}$. Desde esta perspectiva, en la interpretación de los arts.

relación se reconocía a favor de quienes no ostentaban potestad alguna sobre el menor (abuelos, parientes y allegados).

43 En esa medida, debe valorarse positivamente el cambio de perspectiva que la nueva redacción de este precepto evidencia. Pero, también pone de manifiesto, una vez desligado este derecho de relación del estricto ámbito de la patria potestad y reconocido que este también es un derecho del menor que igualmente tiene derecho a que su interés sea considerado como prioritario en dichas relaciones, a tenor del art. 2 LO 1/1996, que, quizás, un mayor rigor sistemático que, además, evitaría un falso entendimiento y esquivaría equívocos, hubiera aconsejado el trasvase de su regulación a otro ámbito o a otro contexto normativo diferente. Acaso esa regulación tendría hoy, pues, mejor acomodo en el ámbito de la LO 1/1996.

44 Téngase en cuenta que en el supuesto en que existiera un conflicto de interés con sus representantes legales (titulares de la patria potestad o de la tutela) resultaría obligado el nombramiento de un defensor judicial (arts. 163 CC; 2.5 de la LO 1/1996 y 27 a 32 de la LJV).

45 No obstante, téngase en cuenta que el ATC 47/2009, de 13 de febrero (RTC 2009, 47 Auto) identifica, como bienes fundamentales en juego en los procedimientos de desamparo, acogimiento y adopción, al derecho a la integridad moral del menor subsumible en el art. 15 CE.

46 Véanse SSTDEH 12.7.2001 — caso K.T contra Finlandia- (TEDH 2001, 467) y 1.6.2004 —asunto Lebbink contra Holanda- (JUR 2004, 185243). Por eso, el TEDH entiende que la vida familiar «incluye al menos los vínculos con los parientes cercanos, tales como el de abuelos y nietos [S.13.6.1979 — asunto Marckx contra Bélgica- (TEDH 1979, 2)]. Asimismo, véanse SSTEDH 13.7.2000 —asunto Elsholz contra Alemania - (TEDH 2000, 15216); 3.12.2009 —asunto Zaunegger contra Alemania- (JUR 2009, 473440); 17.1.2012 —asunto Kopf and Liberda contra Austria- (JUR 2012, 14910); 12.2014 —asunto Chbihi Loudoudi y otros contra Bélgica- (TEDH 2014, 101); 20.1.2015 —asunto Manuello y Nevi con- 
160 y $161 \mathrm{CC}$, debe atribuirse al concepto de «familia» un sentido amplio, tal y como en ese sentido aconseja entender el Comité de los Derechos del Niño ${ }^{47}$. Y así también parece asumirlo el legislador de 2015. Buena prueba de ello es que, ahora, tras la reforma, entre los sujetos con los que el menor tiene derecho a relacionarse se mencionen expresamente, referencia aparte a los padres, abuelos, hermanos ${ }^{48}$, parientes y allegados a quienes hacen alusión los arts. 160 y $161 \mathrm{CC}$, a los exacogedores familiares del menor [art. 20 bis.1.m) LO $1 / 1996]^{49}$ e, incluso, se abre la posibilidad de una relación del menor con sus exparientes tras su adopción por otra familia, tal y como así prevé, para la denominada adopción abierta, el art. 178.4 $\mathrm{CC}^{50}$.

En consecuencia, resulta posible afirmar que este derecho de relación y comunicación pretende salvaguardar unos vínculos de afecto, unas relaciones personales que el derecho de visita pretende potenciar para así favorecer el pleno desarrollo de la personalidad del menor, por lo que también a tal fin se ha de reconocer legitimación para hacerlo efectivo a las personas que han protagonizado o protagonizan esa corriente de afecto $^{51}$.

tra Italia- (TEDH 2015, 16); 27.1.2015 —asunto Paradiso y Campanelli contra Italia- (TEDH 2015, 17). Pero también estima que el derecho a la vida privada incluye "el derecho de la persona a desarrollar relaciones con sus semejantes» [STEDH 27.1.2015 — asunto Paradiso y Campanelli contra Italia — (TEDH 2015, 17)].

47 Conviene así advertir que para el Comité de los Derechos del Niño (2013), el término «familia» debe interpretarse en un sentido amplio o la comunidad, según establezca la costumbre local (art. 5).

De otra parte, no conviene tampoco obviar que el TC considera, al interpretar el art. 39.1 CE, que este precepto no constriñe el concepto de «familia» al que este precepto se refiere [véanse por ejemplo, SSTC 222/1992 (RTC 1992, 222) y 74/1997 de 21 abril (RTC 1997, 74).

48 La referencia expresa a los hermanos constituye una novedad introducida en el texto de los arts. 160 y 161 por la Ley 26/2015.

49 Véase STEDH 17.1.2012 —asunto Kopf and Liberda contra Austria- (JUR 2012, 14910) en la que se aprecia que se ha vulnerado el art. $8 \mathrm{CEDH}$ ante la denegación a los antiguos acogedores familiares de un menor de toda relación con él una vez alcanzada la reinserción familiar.

50 Sobre el particular, véase Sabater Bayle (2016: 325-328).

51 Véase las consideraciones que, sobre este particular, realizaba Rivero Hernández (1997: 376)). Este es, de otra parte, el entendimiento que de este derecho de visita acoge el Tribunal Supremo, al manifestar [S. 12.5.2011 (RJ 2011, 3280)] que «el niño no puede ver recortada la relación y comunicación con personas que le son próximas humana y afectivamente». Por tanto, «el interés del menor obliga a los tribunales a decidir que el niño tiene derecho a relacionarse con los miembros de su familia, con independencia de que entre ellos existan o no lazos biológicos», puesto 
Por tanto, el derecho del menor a relacionarse con sus padres, abuelos, hermanos, parientes y otros allegados encuentra de esta forma su justificación. Pero también ese mismo respeto a la vida privada y familiar y ese derecho a las relaciones personales (art. $8 \mathrm{CEDH}$ ) ha de reconocerse a estos padres, a estos abuelos, a esos hermanos y a esos parientes y allegados, aunque tales derechos resulten modulados por el necesario respeto que merecen los derechos del menor y su misma personalidad, tal y como así hoy resulta claramente de lo dispuesto en el art. 2 LO 1/1996.

Por eso mismo, no pueden verse estos derechos como meros derechos subjetivos atribuidos para la satisfacción del interés del titular, sino que participan de la naturaleza de los derechos-función que, por eso, resultan subordinados en su ejercicio, al interés del menor ${ }^{52}$. En esa línea, cabe defender que los derechos de los arts. 160 y $161 \mathrm{CC}$ constituyen un «complejo de derechos-deberes cuyo adecuado cumplimiento tiene por finalidad satisfacer «las necesidades afectivas y educativas de los hijos en aras de un desarrollo armónico y equilibrado " ${ }^{53}$. Por ello, ese derecho que puede encuadrarse «entre los de la personalidad y que se fundamenta principal, aunque no exclusivamente, en una previa relación familiar entre visitante y visitado ${ }^{54}$, puede también resultar restringido en atención al interés del menor.

En esa línea, la jurisprudencia del Tribunal Europeo de Derecho Humanos se ha mostrado constante a la hora de encuadrar ese derecho de visita o ese derecho de relación en el ámbito del derecho a la vida privada $y$ familiar que el art. $8 \mathrm{CEDH}$ reconoce y garantiza ${ }^{55}$. Sostiene, así, que

que, como se llega a aclarar en la STC 176/2008, de 22 de diciembre (RTC 2008, 176), así como en la STS 11.2.2011 (RJ 2011, 2311), ese derecho de relación contribuye «al desarrollo de la personalidad afectiva de cada uno de ellos». Últimamente, véase STS 27.6.2016 (RJ 2016, 3718).

52 Rivero Hernández (1997: 394).

53 SAP Córdoba 13.5.2004 (JUR 2004, 199432).

54 SAP Córdoba 13.5.2004 (JUR 2004, 199432).

55 Entre otras, véanse SSTEDH 5.12.2002 —asunto Hoppe contra Alemania(TEDH 2002, 72); 23.9.2003 —asunto Hansen contra Turquía- (TEDH 2003, 54); 23.6.2005 —asunto Zawadka contra Polonia (TEDH 2005, 69); 13.7 .2006 —asunto Lafargue contra Rumanía- (JUR 2006, 204580); 28.2.2008 —asunto Andelova contra República Checa- (JUR 2008, 64114); 8.7.2010 —asunto Döring contra Alemania- (TEDH 2010, 82); 2.9.2010 — asunto Mincheva contra Bulgaria (TEDH 2010, 91); 2.11.2010 —asunto Piazzi contra Italia (JUR 2010, 360648); 24.5.2011 —asunto Saleck Bardi contra España- (TEDH 2011, 50); 17.12.2013 —asunto Nicolò Santilli contra Italia_ (JUR 2013, 376762); 21.1.2014 —asunto 
este precepto que «tiende esencialmente a prevenir contra las injerencias arbitrarias de los poderes públicos, pone a cargo del Estado obligaciones positivas inherentes al respecto efectivo de la vida familiar» ${ }^{56}$. Por tanto, «donde la existencia de un vínculo familiar ha sido probada, el Estado debe, en principio, actuar de manera que permita que dicho vínculo se desarrolle» ${ }^{57}$. De este modo, se ha mostrado constante a la hora de defender que el art. $8 \mathrm{CEDH}$ (derecho a la vida privada y familiar) ampara el derecho de todo padre o madre a que se adopten las medidas adecuadas que les permitan reunirse con sus hijos y la obligación de las autoridades

Zhou contra Italia- (JUR 2014, 15444); 14.11.2014 — caso Tocarenco contra República de Modavia- (JUR 2014, 266947).

56 Véanse entre otras, SSTEDH 22.6.1989 — asunto Ericcson contra Suecia- (TEDH 1989, 12); 26.5.1994 —asunto Keegan contra Irlanda- ( (TEDH 1994, 21); 25.1.2000 —caso Ignaccolo—Zenide v. Rumanía (TEDH 2000, 14); 12.7.2001 — caso K. y T. contra Finlandia- (TEDH 2001, 467); 26.2.2002 —caso Kutzner contra Alemania (JUR 2002, 90046); 24.2.2009 —asunto Errico contra Italia- (TEDH 2009, 26); 13.10.2009 —asunto Costreie contra Rumanía (TEDH 2009, 105); 8.6.2010 —asunto Wojciech Nowark contra Polonia- (JUR 2010, 189508); 18.10.2011 —asunto Lyubenova contra Bulgaria- (TEDH 2011, 83); 20.12. 2011 —asunto Prodelalovà contra República Checa- (TEDH 2011, 111); 10.4.2012 —asunto Pontes contra Portugal- (JUR 2012, 128599); 12.4.2011 —asunto Gluhakovic contra Croacia- (JUR 2011, 113684); 3.11.2011 —asunto Kuscuoglu contra Turquía - (TEDH 2011, 91); 11.12.2012 —asunto Ball contra Andorra- (TEDH 2012, 118); 13.11.2012 —asunto Y.U. contra Rusia- (JUR 2012, 353636); 17.1.2012 — asunto Kopf and Liberda contra Austria- (JUR 2012, 14910) 8.1.2013 —asunto Qama v. contra Albania- (TEDH, 2013, 3); 18.6.2013 —asunto RMS contra España- (TEDH 2013, 60); 7.3.2013 —asunto Raw y otros contra Francia- (JUR 2013, 72819); 17.12.2013 —asunto Nicolò Santilli contra Italia- (JUR 2013, 376762); 21.1.2014 —asunto Zhou contra Italia- (JUR 2014, 15444); 16.9.2014 —asunto P.F. contra Polonia- (JUR 2014, 227328); 15.4 .2014 —asunto Krasicki contra Polonia- (JUR 2014, 117850); 14.11.2014 —caso Tocarenco contra República de Moldavia- (JUR 2014, 266947); 2.4.2015 —asunto Ribic contra Croacia- (JUR 2015, 97675); 13.1.2015 — asunto Eugeniu Manic contra República de Lituania- (JUR 2015, 9790); 20.1.2015 — asunto Manuello y Nevi contra Italia - (TEDH 2015, 16); 16.4.2015 —asunto Mitovi contra República de Macedonia- (JUR 2015, 108224); 16.7.2015 —asunto Akinnibosun contra Italia- (JUR 2015, 185807); 16.7.2015 — asunto Mamchur contra Ucrania- (JUR 2015, 185811); 17.11.2015 — asunto Bondavalli contra Italia- (JUR 2015, 272074); 28.4.2016 —asunto Cincimino contra Italia- (JUR 2016, 85031).

57 SSTEDH 21.1.2014 — asunto Zhou contra Italia- (JUR 2014, 15444); 15.4.2014 —asunto Krasicki contra Polonia_ (JUR 2014, 117850). 
públicas de adoptar estas medidas ${ }^{58}$, por lo que corresponde a cada Estado dotarse del arsenal jurídico adecuado y suficiente ${ }^{59}$ para garantizar el cumplimiento de estas obligaciones positivas ${ }^{60}$.

En esa medida, estima que "para un padre y su hijo, estar juntos representa un elemento fundamental de la vida familiar, ${ }^{61}$ o que «el goce conjunto por parte de los padres y de los hijos de la compañía del otro constituye un elemento fundamental de la vida de familia, incluso aunque las relaciones entre los padres se hayan roto" ${ }^{62}$. Por eso mismo, «el hecho de que la Administración Pública se haga cargo de un niño no pone término a las relaciones

58 Entre otras, véanse SSTEDH 5.12.2002 —asunto Hoppe contra Alemania(TEDH 2002, 72); 23.9.2003 —asunto Hansen contra Turquía- (TEDH 2003, 54); 23.6.2005 —asunto Zawadka contra Polonia (TEDH 2005, 69); 13.7.2006 —asunto Lafargue contra Rumanía_- (JUR 2006, 204580); 28.2.2008 —asunto Andelova contra República Checa- (JUR 2008, 64114); 8.7.2010 — asunto Döring contra Alemania - (TEDH 2010, 82); 2.9.2010 — asunto Mincheva contra Bulgaria (TEDH 2010, 91); 2.11.2010 —asunto Piazzi contra Italia (JUR 2010, 360648); 24.5.2011 —asunto Saleck Bardi contra España- (TEDH 2011, 50); 17.12.2013 —asunto Nicolò Santilli contra Italia_ (JUR 2013, 376762); 18.6.2013 —asunto R.M.S. contra España (TEDH 2013, 60); 21.1.2014 — asunto Zhou contra Italia(JUR 2014, 15444); 14.11.2014 — caso Tocarenco contra República de Modavia(JUR 2014, 266947).

59 Por ejemplo, véanse SSTEDH 20.12. 2011 —asunto Prodelalovà contra República Checa- (TEDH 2011, 111); 17.12.2013 —asunto Nicolò Santilli contra Italia(JUR 2013, 376762); 21.1.2014 —asunto Zhou contra Italia- (JUR 2014, 15444); 16.7.2015 —asunto Akinnibosun contra Italia— (JUR 2015, 185807).

60 Véanse, a título ilustrativo, SSTEDH 18.6.2013 — asunto R.M.S. contra España(TEDH 2013, 60); 17.12.2013 —asunto Nicolò Santilli contra Italia- (JUR 2013, 376762); 21.1.2014 — asunto Zhou contra Italia- (JUR 2014, 15444).

61 Véanse por ejemplo, SSTEDH 9.6.1998 — asunto Bronda contra Italia- (TEDH 1998, 27); 13.7.2000 —asunto Elsholz contra Alemania (TEDH 2000, 152); 24.2.2009 — asunto Errico contra Italia - (TEDH 2009, 26); 13.10.2009 —asunto Costreie contra Rumanía (TEDH 2009, 105); 3.12.2009 —asunto Zaunegger contra Alemania- (JUR 2009, 473440); 27.9.2011 —asunto M. y C. contra Rumanía(TEDH 2011, 75); 8.7.2010 — asunto Döring contra Alemania- (TEDH 2010, 82); 10.2.2011 —asunto Tsikakis contra Alemania- (JUR 2011, 37824); 12.4.2011 —asunto Gluhakovic contra Croacia- (JUR 2011, 113684); 13.1.2015 —asunto Eugeniu Manic contra República de Lituania- (JUR 2015, 9790); 20.1.2015 —asunto Manuello y Nevi contra Italia- (TEDH 2015, 16); 2.4 .2015 —asunto Ribic contra Croacia- (JUR 2015, 97675); 28.4.2016 — asunto Cincimino contra Italia- (JUR 2016, 85031).

62 STEDH 5.12.2002 —asunto Hoppe contra Alemania- (TEDH 2002, 72). 
familiares», por lo que cualquier restricción acordada en vía administrativa supone una injerencia en la vida privada y familiar ${ }^{63}$, aunque, tal y como se verá, esta intrusión, con ciertos requisitos y garantías, resulte autorizada para amparar debidamente el interés del menor.

\section{EL DERECHO A UNA VIDA EN FAMILIA Y EL DERECHO A LA PROPIA FAMILIA}

Tratándose de un menor afecto a la intervención de la entidad pública y separado de su núcleo afectivo de origen, el mantenimiento de su relación con su familia resulta indispensable para asegurar su posible reinserción familiar una vez vencidos los obstáculos que determinaron su alejamiento temporal de ella ${ }^{64}$.

Y, como se verá, es interés del menor, que se relaciona, como se ha visto, con su derecho a la vida privada y familiar, con su derecho a la identidad y al libre desarrollo de la personalidad, el crecer y ser educado en el seno de su propia familia. Sin embargo, también ha de advertirse que no siempre resultará ni posible ni viable esa reinserción y que también es interés del menor el tener una vida en familia, aunque esta no sea la suya propia. Pues bien, es en esa tensión entre ambos criterios delimitadores del interés del menor, donde gravitan todos los eventuales conflictos que, en el fondo, subyacen en el art. $161 \mathrm{CC}^{65}$.

Ese interés del menor a la propia familia es un derecho que se encuentra reflejado explícitamente en la Convención de 20 de noviembre de 1989 sobre los Derechos del Niño ${ }^{66}$ (art. 9.1), así como en las Directrices sobre las modalidades alternativas de cuidado de niños aprobadas por la Resolución 64/142 de la Asamblea General de las Naciones Unidas, de 18 de diciembre de $2009^{67}$.

63 STEDH 24.3.1988 —asunto Olsson contra Suecia- (TEDH 1988, 2). Igualmente, véase STEDH 27.9.2011 —asunto M. y C. contra Rumanía- (TEDH 2011, 75).

64 Precisamente, en atención a la inviable reinserción familiar, pero también a la inexistencia de vínculo afectivo entre un progenitor y su hija, en prisión desde que esta nació cumpliendo condena por un delito de violencia de género contra la madre de la niña, la SAP Barcelona 5.2.2013 (JUR 2013, 115262) considera procedente suspender toda relación entre padre e hija.

65 Véase también, art. 228-8 del Código Civil de Cataluña.

66 Instrumento de ratificación, BOE 313, de 31 de diciembre de 1990.

67 ONU (2010). Tal y como declara la directriz 13a , «la separación del niño de su propia familia debería considerarse como medida de último recurso, y en lo posible, ser temporal y por el menor tiempo posible». 
Pues bien, el art. 11.2 LO 1/1996, al enunciar los principios rectores de la actuación de los poderes públicos en relación con los menores, realiza, en primer lugar, una referencia en su apartado a) a la supremacía del interés del menor, y en el b) hace expresa mención al «mantenimiento en su familia de origen, salvo que no sea conveniente para su interés» ${ }^{68}$.

Por su parte, el art. 2.2.c) LO 1/1996, tras la reforma de 2015, reconoce que es interés del menor tener una «vida en familia»" ${ }^{69}$, lo que es lo mismo, es para él conveniente que "su vida y desarrollo tenga lugar en un entorno familiar adecuado y libre de violencia», aunque, obviamente, esa familia no sea la suya de origen. Pero, al tiempo, se afirma en este precepto en su apartado d) que es también su interés preservar su identidad para así garantizar «el desarrollo armónico de su personalidad» a cuyo fin puede resultar también necesario que el menor conserve los lazos afectivos con su núcleo familiar de procedencia. Por eso mismo, y aun cuando el menor sea separado de su familia de origen es también interés suyo, conforme al art. 2.2. c) LO 1/1996, que se preserve «el mantenimiento de sus relaciones familiares, siempre que sea posible y positivo para el menor».

En esa línea, el $\mathrm{TEDH}^{70}$ ha considerado igualmente que es interés del menor, a tenor del art. $8 \mathrm{CEDH}$, asegurar el mantenimiento de la relación del niño con su familia («allí donde queda establecida la existencia de un vínculo familiar con un niño, el Estado debe actuar para permitir que este vínculo se desarrolle y proporcione una protección legal que haga posible la integración del niño en su familia $»^{71}$ ), «excepto en el caso en el que esta se haya mostrado indigna, ya que romper esta relación equivale a desarraigar al menor» ${ }^{72}$. Por

68 Art. 3 de la Convención de los Derechos del Niño según se entiende en la OB 14, $\$ 1$.

69 En sus conclusiones, la Comisión Especial, constituida en el Senado, para el Estudio de la Problemática de la Adopción Nacional y Otros Temas Afines, estimaba que «todo niño o niña que durante los tres primeros años de vida no haya podido establecer vínculos seguros con una o dos personas estables, va a ver afectado su desarrollo personal de forma muy significativa para confiar en el ser humano, aprender de la experiencia, comprender y regular las propias emociones, tener autoestima, relacionarse o aprender a convivir (BOCG, Senado, 545, 17 de noviembre de 2010, 46-48).

70 Para un estudio de la doctrina del TEDH en la materia, véase Salanova Villanueva (2003: 426) y Ferrer I Riba (2010: 1-31).

71 Véanse SSTEDH 28.6.2007 —asunto Wagner y J.M.W.L. contra Luxemburgo(JUR 2007, 147388); 16.12.12.2014 —asunto Chbihi Loudoudi y otros contra Bélgica- (TEDH 2014, 101); 28.4.2016 —asunto Cincimino contra Italia- (JUR 2016, 85031).

72 Entre otras, véanse SSTEDH 19.9.2000 —asunto Gnahore contra Francia(TEDH 2000, 440); 6.12.2007 —caso Maumousseau vs. Francia- (TEDH 2007, 
tanto, es interés del niño que por las autoridades deba hacerse cualquier cosa para mantener las relaciones y, dado el caso, en un momento dado, «reconstruir» la familia»" ${ }^{73}$. En esa medida, "la asunción de la tutela del niño debe considerarse como una medida temporal a suspender tan pronto como la situación se preste», por lo que «cualquier acto de ejecución debe ser coherente con un objetivo final: unir de nuevo al progenitor natural y al niño» ${ }^{74}$. Por este motivo, el art. $8 \mathrm{CEDH}$ obliga a las autoridades nacionales adoptar las medidas capaces de facilitar la reunión familiar ${ }^{75}$. Por esta misma razón, la clave es determinar si las autoridades han agotado «todos los medios que razonablemente puedan ser considerados necesarios para facilitar el contacto en las

88); 8.1.2009 — asunto Neulinger y Shuruk vs. Suiza— (TEDH 2009, 6); 12.2.2013 —asunto Vojnity contra Hungría. (TEDH 2013, 18); 16.7.2015 —asunto Mamchur contra Ucrania- (JUR 2015, 185811); 28.4.2016 — asunto Cincimino contra Italia- (JUR 2016, 85031). Por tanto, la ruptura total del contacto solo puede admitirse en circunstancias excepcionales [SSTEDH 8.7.1987 — asunto B. contra Reino Unido (TEDH 1987,16); 12.2.2013 —asunto Vojnity contra Hungría. (TEDH 2013, 18)].

73 SSTEDH 26.5.2009 —asunto Amanalachioi contra Rumanía- (TEDH 2009 59); 18.6.2013 —asunto RMS contra España- (TEDH 2013, 60); 15.4.2014 —asunto Krasicki contra Polonia- (JUR 2014, 117850); 27.1.2015 —asunto Paradiso y Campanelli contra Italia- (TEDH 2015, 17). Asimismo, véase STEDH 22.10.2015 —asunto Jovanovic contra Suecia- (JUR 2015, 246772).

74 STEDH 18.6.2013 —asunto R.M.S. contra España (TEDH 2013, 60). Igualmente, véanse STEDH 16.7.2015 —asunto Akinnibosun contra Italia- (JUR 2015, 185807) y 16.7.2015 —asunto Mamchur contra Ucrania- (JUR 2015, 185811). Por eso mismo, el transcurso del tiempo (dos años) durante el cual una madre ha sido privada del contacto con su hijo en virtud de un régimen provisional es suficiente para entender que no resultará previsible que puedan ser luego sanadas las relaciones entre esa progenitora y su hijo menor. Por tanto, en esas condiciones, ante la ausencia de una resolución definitiva, el TEDH entendió que no se adoptaron por las autoridades nacionales todas las medidas que razonablemente podía exigirse de su parte para garantizar los derechos del art. 8.1 CEDH. Véase STEDH 20.12.2011 —asunto Prodelalovà contra República Checa- (TEDH 2011, 111). No obstante, no faltan las decisiones judiciales en las que la suspensión definitiva de relaciones entre el menor y su familia de origen se funda, precisamente, en la necesidad de favorecer la definitiva integración del menor en su nuevo ámbito familiar [Véase por ejemplo, SAP Santa Cruz de Tenerife 12.1.2012 (JUR 2012, 90917)].

75 SSTEDH 25.1.2000 —caso Ignaccolo-Zenide v. Rumanía (TEDH 2000, 14); 12.7.2001 —caso K. y T. contra Finlandia- (TEDH 2001, 467); 26.2.2002 — caso Kutzner contra Alemania (JUR 2002, 90046); 24.2.2009 (TEDH 2009, 26); 11.12.2012 — asunto Ball contra Andorra- (TEDH 2012, 118). 
circunstancias especiales de cada caso ${ }^{76}$. Pero esa obligación no es absoluta, pues pueden darse situaciones en los que los contactos no pueden tener lugar inmediatamente o en los que su planificación exija preparativos o una graduación ${ }^{77}$. Pero también requiere una participación activa de los progenitores, por lo que si esta no se da, no existirá vulneración de ese art. $8 \mathrm{CEDH}^{78}$.

En consecuencia, ese derecho del menor a crecer y ser educado por su propia familia que puede ser perfectamente calificado como un derecho subjetivo perfecto ejercitable erga omnes o como derecho fundamental ${ }^{79}$ subordinado a su interés, permite afirmar la ilegitimidad de cualquier procedimiento judicial o administrativo dirigido a privarle de su propia familia fuera de los casos previstos por la ley. Pero también admite reconocer que el derecho de los padres o de los miembros de su núcleo afectivo de procedencia de tener consigo al menor — cualificable como derecho de la personalidad ${ }^{80}$ —, se halla igualmente afecto al mismo límite. Por tanto, ese derecho del menor no tiene carácter absoluto, ya que su propio interés puede hacer necesarias otras medi$\mathrm{das}^{81}$. De este modo, este eventual derecho de los miembros de la familia de origen solo debe ceder en atención a un principio superior, como es el interés del propio menor, pero solo en la medida en que con ello se asegure su bienestar. En este orden de cosas, solo cabrá acordar el alejamiento del niño de su núcleo familiar en los supuestos excepcionales en que su permanencia en él le sea perjudicial, tal y como así consideró, en su momento, nuestro Tribunal Constitucional ${ }^{82}$.

Además, esa prioridad resulta de las previsiones contenidas en la $\mathrm{Ob}$ servación General 14 (2013) del Comité de los Derechos del Niño sobre el derecho del niño a que su interés superior sea una consideración primordial ${ }^{83}$ (véanse art. 10.2 CE y art. 3 LO 1/1996). Pues bien, entre ellas se considera explícitamente que, "prevenir la separación familiar y preservar la unidad fa-

76 SSTEDH 2.2.2010 — asunto Dabrowska contra Polonia-(TEDH 2010, 21); 3.11.2011 —asunto Kuscuoglu contra Turquía — (TEDH 2011, 91) 16.7.2015 — asunto Mamchur contra Ucrania- (JUR 2015, 185811).

77 SSTEDH 13.10.2009 —asunto Costreie contra Rumanía (TEDH 2009, 105);

3.11.2011 —asunto Kuscuoglu contra Turquía- (TEDH 2011, 91); 11.12.2012

—asunto Ball contra Andorra- (TEDH 2012, 118).

78 Véase STEDH 11.12.2012 — asunto Ball contra Andorra- (TEDH 2012, 118).

79 Véase Bianca (2002: 910).

80 Véase Bianca (2002: 909).

81 STS 13.6.2011 (RJ 2011, 4526).

82 STC 71/2004, de 19 de abril (RTC 2004, 71). Igualmente véase ATSJ Cataluña 12.1.2012 (JUR 2012, 75142).

83 OB $14, \$ 58$ a 70 . 
miliar» son elementos importantes del régimen de protección del niño, y se basan en el derecho recogido en el artículo 9, párrafo 1, que exige «que el niño no sea separado de sus padres contra la voluntad de estos, excepto cuando [...] tal separación es necesaria en el interés superior del niño» ${ }^{84}$. Por eso mismo, «dada la gravedad de los efectos en el niño de que lo separen de sus padres, dicha medida solo debería aplicarse como último recurso, por ejemplo, cuando el niño esté en peligro de sufrir un daño inminente o cuando sea necesario por otro motivo; la separación no debería llevarse a cabo si se puede proteger al niño de un modo que se inmiscuya menos en la familia» ${ }^{85}$. Y, por eso mismo, cuando la separación del menor de su familiar se torne en necesaria, "los responsables de la toma de decisiones velarán porque el niño mantenga los lazos y la relación con sus padres y su familia (hermanos, familiares y personas con las que el niño haya tenido una relación personal estrecha), a menos que ello contravenga el interés superior del niño» ${ }^{86}$. Y en la toma de decisiones sobre la periodicidad y la duración de las visitas y otras formas de contacto, deberán «tenerse en cuenta la calidad de las relaciones y la necesidad de conservarlas» ${ }^{87}$.

En esa línea, el apartado 2 del art. 172 ter CC — precepto introducido por la Ley 26/2015 - declara, como objetivo prioritario de todo acogimiento, sea este familiar o residencial, la reagrupación familiar y, por tanto, el retorno del niño a su núcleo familiar de procedencia. Ahora bien, la entidad pública tiene atribuida el poder de valorar y de decidir — sin perjuicio de que su actividad esté sujeta a la correspondiente fiscalización judicial— si, en verdad, ese retorno del menor a su familia de origen resulta o no viable para así decidir si, como contenido del plan individualizado de protección que tiene el deber de elaborar y de aplicar, se ha de incluir o no un programa de reintegración familiar (art. 19.bis. 1 y 2 LO 1/1996) ${ }^{88}$, programa que, en caso de guarda voluntaria, ha de comprender también el compromiso de la familia de someterse a una intervención profesional (art. 19.2 in fine LO 1/1996).

Pues bien, para facilitar la reintegración familiar resulta esencial que ese programa preserve las relaciones del menor con su núcleo familiar de origen. A tal fin, el art. 21 bis.1.d) LO 1/1996 — precepto añadido por el art. 1.17 Ley 26/2015 - recuerda que todo menor acogido, cualquiera que sea la modalidad de acogimiento a la que esté sometido, tiene derecho a «relacionarse con su familia de origen en el marco del régimen de visitas, relación y comuni-

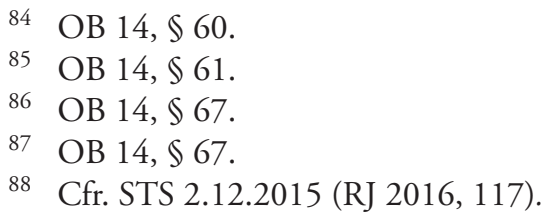


cación establecido por la entidad pública». Correlativamente, por este motivo, las entidades públicas y los servicios y centros donde se encuentre acogido el menor en régimen de acogimiento residencial tienen la obligación de promover «la relación y colaboración familiar, programándose, al efecto, los recursos necesarios para posibilitar el retorno a su familia de origen, si se considera que ese es el interés del menor» [art. 21.1.e) LO 1/1996]. Y, por eso mismo, los acogedores familiares tienen el deber de respetar y facilitar las relaciones con la familia de origen del menor, en el marco del régimen de visitas establecido a favor de aquélla» [art. 20 bis.2.e) LO 1/1996], y, en su caso, favorecer la reintegración familiar, a cuyo fin asumen también el deber de «colaborar en el tránsito de la medida de protección del menor a la reintegración a su entorno de origen» [arts. 20.bis.2.k)] ${ }^{89}$. De ahí también que en el documento anexo a la resolución administrativa de formalización del acogimiento familiar haya de constar «el régimen de visitas, estancia, relación o comunicación, en los supuestos de declaración de desamparo, por parte de la familia de origen, que podrá modificarse por la entidad pública en atención al interés superior del menor» [art. 20.3.d).1 $\left.1^{\circ} \mathrm{LO} 1 / 1996\right]^{90}$.

89 En la evaluación de la idoneidad de los acogedores, la entidad pública debe tener en cuenta su «disposición a facilitar el cumplimiento de los objetivos del plan individual de atención y, si lo hubiera, del programa de reintegración familiar, propiciando la relación del menor con su familia de procedencia» (art. 20.2 LO 1/1996).

90 A nadie se le oculta, de otra parte, que en ese proceso deberá reputarse esencial, en orden a favorecer esas relaciones, la proximidad física entre el núcleo de acogida — sea este familiar o no- y la familia de origen a la que previsiblemente podrá reincorporarse el menor, tal y como así hoy reconoce implícitamente para el acogimiento residencial el art. 21.1.d) LO 1/1996, al declarar que se habrá de procurar que ese acogimiento tenga lugar preferentemente en un centro ubicado en la provincia de origen del menor.

De otra parte, procediendo el retorno del menor a su núcleo afectivo de origen, puede también resultar aconsejable que este se realice de forma paulatina, por lo que puede ser prudente establecer un progresivo sistema de acercamiento mediante la ampliación del régimen de relaciones personales que se hubiera establecido previamente, adoptándose, si así se estima conveniente, las cautelas oportunas. Por otro lado, esas visitas no han de interferir en la vida escolar o social de los menores (art. 15 LO 1/1996). Pero, además, no resulta posible entender que el respeto a las visitas por los acogedores familiares determine una afectación a sus derechos fundamentales del art. $18 \mathrm{CE}$ obligándoles, en contra de su voluntad, a facilitar la relación en su propio domicilio. Así parece entenderlo el legislador, al señalar, en el art. 20.2 LO 1/1996, que esas visitas puedan tener lugar en los puntos de encuentro familiar habilitados, "cuando así lo aconseje el interés superior del menor y el derecho a la privacidad de las familias de procedencia y acogedora». 
En esa medida, y puesto que la finalidad de toda medida de protección ha de ser procurar el retorno del menor con su familia de origen ${ }^{91}$, por lo que, por eso mismo, tiene una naturaleza esencialmente temporal ${ }^{92}$ e impone a las autoridades públicas la obligación positiva ${ }^{93}$ de adoptar cuantas medidas sean necesarias para facilitar la reunión familiar ${ }^{94}$, toda restricción

91 Véase STEDH 26.2.2002 — asunto Kutzner contra Alemania- (JUR 2002,90046)]. En este caso, el Tribunal de Estrasburgo entendió que la decisión de la autoridades familiares de que dos hermanas menores fueran colocadas en familias acogedoras separadas, tras intentos infructuosos de auxilio familiar, en atención también a las limitaciones intelectivas y volitivas de sus padres y de imposibilitar todo contacto con sus progenitores a los que no se concedió derecho de visita alguno, había conducido a un distanciamiento creciente entre padres e hijas y también entre las dos niñas que no estaba en modo alguno justificado en el interés de las menores ni resultaba proporcionada. Y es que tal y como se relata en los antecedentes de esta resolución judicial y expuso la defensa de estos padres ante el TEDH a estos progenitores, "les era insoportable verse reprochar su bajo nivel intelectual, ya que si se aplicaran esos criterios, a alrededor del $30 \%$ de los padres en Alemania se les retiraría la patria potestad sobre sus hijos».

92 De este modo, no cabe afirmar que las autoridades han realizado los esfuerzos necesarios para posibilitar la reunificación familiar cuando solo se autoriza un único contacto entre un progenitor y su hija menor tras no existir una relación entre ellos durante tres años, debido a la falsa imputación a ese padre de un delito que lo retuvo en prisión, sin que, además, se hubiera realizado pericia alguna que determinase sus habilidades para ejercer las responsabilidades parentales o que determinase el estado psicológico de la menor [STEDH 16.7.2015 — asunto Akinnibosun contra Italia(JUR 2015, 185807)].

93 STEDH 23.6.2005 —asunto Zawadka contra Polonia (TEDH 2005, 69). Véanse SSTEDH 4.9.2014_—asunto Drenk contra República Chec (JUR 2014, 223068); 17.12.2013 — asunto Nicolò Santilli contra Italia— (JUR 2013, 376762).

94 Entre otras, véanse SSTEDH 5.12.2002 —asunto Hoppe contra Alemania(TEDH 2002, 72); 23.9.2003 —asunto Hansen contra Turquía- (TEDH 2003, 54); 23.6.2005 —asunto Zawadka contra Polonia (TEDH 2005, 69); 13.7.2006 — asunto Lafargue contra Rumanía- (JUR 2006, 204580); 28.2.2008 —asunto Andelova contra República Checa- (JUR 2008, 64114); 8.7.2010 —asunto Döring contra Alemania- (TEDH 2010, 82); 2.9.2010 —asunto Mincheva contra Bulgaria (TEDH 2010, 9); 2.11.2010 —asunto Piazzi contra Italia (TEDH 2010, 82); 24.5.2011 —asunto Saleck Bardi contra España- (TEDH 2011, 50); 17.12.2013 —asunto Nicolò Santilli contra Italia- (JUR 2013, 376762); 21.1.2014 —asunto Zhou contra Italia- (JUR 2014, 15444); 14.11.2014 — caso Tocarenco contra República de Moldavia- (JUR 2014, 266947). 
suplementaria o añadida ${ }^{95}$, cual puede ser el limitar o restringir las relaciones personales del niño con su entorno de procedencia, puede llegar a constituir una injerencia injustificable en la vida privada y familiar del propio menor o de los sujetos privados de su compañía o comunicación que además puede llegar a incidir negativamente en su propio desarrollo personal y afectivo ${ }^{96}$, salvo, de nuevo, si esas medidas accesorias al apartamiento resultan absolutamente necesarias para salvaguardar el interés del menor y resultan proporcionadas al fin perseguido ${ }^{97}$.

Ahora bien, debe advertirse, como ya se ha sugerido, que ese derecho del menor desamparado a relacionarse con su familia de origen y a reinsertarse en ese núcleo familiar y el correlativo derecho de los miembros de esa familia a

95 El TEDH considera que "hay que ejercer un control más riguroso a la vez sobre las restricciones complementarias, como las que practican las autoridades sobre los derechos y las visitas de los padres y sobre las garantías destinadas a garantizar la protección efectiva del derecho de los padres y los hijos al respeto de su vida familiar», pues «esas restricciones complementarias comportan el riesgo de amputar las relaciones familiares entre los padres y un niño de corta edad, porque pueden conducir a un deterioro cada vez mayor de la relación con el progenitor». Véase STEDH 24.5.2011 —asunto Saleck Bardi contra España- (TEDH 2011, 50) y las SSTEDH 13.7.2000 — asunto Elsholz contra Alemania- (TEDH 2000,15226); 8.7.2003 — asunto Sommerfeld contra Alemania- (JUR 2003, 162887); 26.5.2009 —asunto Amanalachioia contra Rumanía- (TEDH 2009, 59); 20.1.2011 —asunto Rytchenko contra Rusia-(JUR 2011, 14350); 10.2.2011 —asunto Tsikakis contra Alemania- (JUR 2011, 37824); 7.3.2013 — asunto Raw y otros contra Francia- (JUR 2013, 72819) y 4.9.2014 —asunto Drenk contra República Checa- (JUR 2014, 223068). Igualmente, véanse SSTEDH 14.3.2013 —asunto B.B. y F.B. contra Alemania- (TEDH 2013, 30); 27.1.2015 —asunto Paradiso y Campanelli contra Italia- (TEDH 2015, 17) y 28.4.2016 —asunto Cincimino contra Italia- (JUR 2016, 85031).

96 Véase el supuesto examinado por la STEDH 26.11.2009 —asunto Vautier contra Francia- (TEDH 2009, 126) en el que suspendidas las visitas de la madre a sus hijas afectas a un acogimiento en lugar secreto por la conducta hostil de esta progenitora hacia el personal de los servicios sociales, tuvo finalmente la autoridad judicial que ordenar la reagrupación familiar debido a las consecuencias nefastas que, para la salud psíquica de las niñas, generaba ese acogimiento.

97 En parecido sentido, véase STS 4.11.2013 (RJ 2013,7074). Por eso mismo, en el caso examinado por la STEDH 18.6.2013 — asunto R. M. S. contra España (TEDH 2013, 60) se entendió que las autoridades españolas, ante la situación de indigencia de la progenitora de una menor, debían haber intentado medidas menos drásticas que su declaración de desamparo. 
que retorne el menor bajo su cobijo, no es un derecho absoluto, sino modulado por su propio interés, tal y como ahora resulta claramente de la dicción del art. 2.2.c) LO 1/1996. De este modo, ese interés puede aconsejar su alejamiento, a veces definitivo, de ese núcleo familiar de procedencia. Por tanto, si bien es su interés tener una vida en familia que, para menores de cierta edad tras la reforma, deviene en un deber imperativo a procurar por la entidad pública (art. 21.3 LO 1/1996), esa familia no tiene por qué ser necesariamente la suya propia.

En esa línea, conviene recordar que el mismo art. 8.2 $\mathrm{CEDH}^{98}$ admite una posible injerencia pública en el ejercicio de estos derechos siempre que dicha intrusión esté autorizada por ley, sea necesaria en una sociedad democrática ${ }^{99} \mathrm{y}$, además, tal y como exige el TEDH, resulte proporcionada ${ }^{100}$. Y, por eso mismo, debe también observarse que cualquier medida adoptada por el poder público en el ámbito familiar supondría una injerencia proscrita por el art. $8 \mathrm{CEDH}$ si el procedimiento en que se hubiera dictado no hubiera respetado las garantías procesales o no hubiera sido atento a los derechos de los progenitores ${ }^{101}$. Veamos entonces si la intromisión de la entidad pública cumple o no con tales exigencias.

98 Véase por ejemplo, la doctrina de las SSTEDH 10.5.2001 —asunto T.P. y K.M. contra Reino Unido- (TEDH 2001, 331); 10.10 .2002 —asunto D. P. y J. C. contra el Reino Unido- (TEDH 2002, 54); 17.12.2002 —asunto Venema y Venema-Huiting contra Países Bajos- (TEDH 2002, 75); 14.1.2003—asunto K. A. contra Finlandia (JUR 2003, 50027); 18.2.2003 — asunto Schaal contra Luxemburgo_-(JUR 2003, 244793); 9.5.2003—asunto Covezzi y Morselli contra Italia- (TEDH 2003, 24); 21.9.2006 —asunto Moser contra Austria- (TEDH 2006, 50); 26.10.2006 —asunto Wallová y Walla contra República checa- (JUR 2007, 252587); 21.6.2007 —asunto Havelka y otros contra República Checa- (TEDH 2007, 42); 25.9.2008 —asunto K.T. contra Noruega- (TEDH 2008, 65); 30.9.2008 —asunto R. K. y A. K. contra Reino Unido- (TEDH 2008, 69); 24.2.2009 —asunto Errico contra Italia- (TEDH 2009, 26); 26.11.2009 —asunto Vautier contra Francia- (TEDH 2009, 126); 16.3.2010 —asunto A. D y O. D. contra el Reino Unido- (TEDH 2010, 50); 24.5.2011 —asunto Saleck Bardi contra España- (TEDH 2011, 50).

99 A los efectos del párrafo 2 del art. 8 de la Convención, la consideración de lo que es en el mejor interés del niño es siempre crucial [SSTEDH 13.7.2000 — asunto Elsholz contra Alemania - (TEDH 2000,15226); 2.2002 — asunto Kutzner contra Alemania- (JUR 2002, 90046); 8.7.2003 — asunto Sommerfeld contra Alemania— (JUR 2003, 162887)].

100 A título de ejemplo, véanse SSTEDH 1.7.2004 — asunto Couillard Maugery contra Francia- (JUR 2006, 204657); 24.2.2009 — asunto Errico contra Italia- (TEDH 2009, 26); 14.3.2013 —asunto B.B. y F.B. contra Alemania- (TEDH 2013, 30); 28.4.2016 - asunto Cincimino contra Italia- (JUR 2016, 85031).

101 Véase STEDH 8.1.2013 —asunto A.K. y L. contra Croacia- (TEDH 2013, 5). 


\section{LA LEGALIDAD DE LA INTRUSIÓN DE LA ENTIDAD PÚBLICA EN LA ESFERA PRIVADA Y FAMILIAR DEL ART. 161 CC}

\section{EL DERECHO DE RELACIÓN DEL ART. 161 CC Y LA RESERVA DE LEY ORGÁNICA DEL ART. 81.1 CE}

Tal y como se ha visto, el texto del art. 161 CC incide claramente en la esfera del ejercicio de los derechos fundamentales reconocidos y consagrados por el art. 18 CE. Pues bien, pese a ello, el legislador de 2015, siguiendo el modo de actuar de sus predecesores, decidió acometer su reforma mediante una ley ordinaria - la Ley 26/2015-, pese a que, simultáneamente, se tramitaba y se aprobaba, a fin de acometer la revisión y la modernización del sistema de protección de la infancia, una ley orgánica que se justificaba en razón de la necesidad de «introducir los cambios jurídicos-procesales y sustantivos necesarios en aquellos ámbitos considerados como materia orgánica, al incidir en los derechos fundamentales y libertades públicas establecidos en los artículos $14,15,16,17.1,18.2$ y 24 de la Constitución».

Por las razones antes expuestas puede cuestionarse la decisión del legislador de excluir esa regulación de las relaciones del menor con su núcleo afectivo de origen de su consideración como materia orgánica. No obstante, también ha de reconocerse que el Tribunal Constitucional ha mantenido una doctrina constante que acota restrictivamente la materia cuya regulación el art. 81.1 reserva a ley orgánica ${ }^{102}$. Así, ha sostenido, tal y como recuerda la STC 151/2014, de 25 de septiembre (RTC 2014, 151), que la disciplina de un derecho fundamental o de una libertad pública de los reconocidos en los arts. 15 a $29 \mathrm{CE}$, únicamente requiere ley orgánica cuando dicha normativa «desarrolle la Constitución de manera directa y en elementos esenciales para la definición del derecho fundamental, ya sea en una regulación directa, general y global del mismo o en una parcial o sectorial, pero, igualmente, relativa a aspectos esenciales del derecho, y no, por parcial, menos directa o encaminada a contribuir a la delimitación y definición legal del derecho» ${ }^{103}$. Es más, ha

102 Tal y como expone la STC 129/1999, de 1 de julio (RTC 1999, 129), recordando la doctrina de las SSTC 5/1981, de 13 de febrero (RTC 1981, 5) y 173/1988, de 3 de octubre (RTC 1998, 173), ese Tribunal «ha destacado de forma ininterrumpida la necesidad de aplicar un criterio estricto para determinar el alcance de la reserva y ello tanto en lo referente al término «desarrollar» como a «la materia» objeto de reserva. Se trata, dice el Tribunal en reiteradas resoluciones, de evitar petrificaciones del ordenamiento y de preservar la regla de las mayorías parlamentarias no cualificadas».

103 Véase STC 127/1994, de 5 de mayo (RTC 1994, 127). Véanse también, SSTC 173/1998, de 23 de julio (RTC 1998, 173) y 129/1999, de 1 de julio (RTC 1999, 129). 
considerado de forma más precisa «que lo que está constitucionalmente reservado a la ley orgánica es la regulación de determinados aspectos esenciales para la definición del derecho, la previsión de su ámbito y la fijación de sus límites ${ }^{104}$ en relación con otras libertades constitucionalmente protegidas ${ }^{105}{ }$.

Aplicando esta doctrina al artículo 161 CC, aquí enjuiciado, cabría entonces afirmar que dicho precepto no contiene una regulación directa del derecho a la intimidad privada o familiar; del derecho a la identidad del menor o de su derecho a la integridad moral encaminada a la delimitación y definición del mismo, por lo que, en consecuencia, esta norma no podría considerarse incluida en el ámbito reservado a la ley orgánica.

No obstante, al admitir este precepto una limitación a los derechos del art. $18 \mathrm{CE}$ (o, si se prefiere, del art. $15 \mathrm{CE}$ ) por una decisión administrativa ante la necesidad de salvaguardar el derecho fundamental del menor a que su interés sea prioritario (art. 2 LO 1/1996), puede llegar a cuestionarse esta afirmación, pues, como también afirmó la STC 129/1999, de 1 de julio (RTC 1999, 129), la reserva de ley orgánica del art. 81.1 CE tiene una función de garantía adicional que conduce a su aplicación a «las normas que establecen restricciones de esos derechos o libertades». Y, este, sería precisamente el caso de ese art. 161 CC, por lo que, de acogerse esta interpretación, habría que afirmar que la limitación o la supresión de las visitas del menor con sus progenitores, abuelos, hermanos, parientes y allegados constituye materia orgánica, por lo que ese precepto, pero también el art. 160 CC, devendrían, por este único motivo, inconstitucionales.

\section{LA CALIDAD DE LA LEY}

Al margen de estas consideraciones que, como se ha visto, resultan del todo punto controvertidas, discutibles y problemáticas en atención a la misma doctrina restrictiva que el Tribunal Constitucional ha construido sobre las materias reservadas a ley orgánica, conviene también aclarar que, cuando el TEDH alude a la exigencia de la legalidad de la intromisión pública en la esfera del ejercicio del derecho a la vida privada y familiar, también se refiere a la calidad de la ley ${ }^{106}$.

104 STC 129/1999, de 1 de julio (RTC 1999, 129).

105 STC 88/1995, de 6 de junio (RTC 1995, 88).

106 También el Tribunal Constitucional se ha referido a que el principio de legalidad, por exigencias de los principios de seguridad jurídica y de certeza del derecho, en el marco de la injerencia en el derecho a la intimidad, requiere «una ley de singular precisión» (véase STC 49/1999, de 5 de abril —RTC 1999, 49-). 
Pues bien, a su entender, esta calidad implica que la ley tiene que ser suficientemente accesible y precisa a fin de evitar todo riesgo de nepotismo ${ }^{107}$, ya que "supone que el derecho interno debe proporcionar determinada protección contra los ataques injustos del poder público a los derechos garantizados entre otros por el apartado 1 del art. $8 »^{108}$.

Por este motivo, quizá se pueda reprochar al art. $161 \mathrm{CC}$ la ausencia de tipificación de las circunstancias y de las causas por las que la entidad pública resulta autorizada para limitar o suspender las visitas del menor con su núcleo afectivo de procedencia, aunque, quizá, la referencia que realiza este precepto al deber de motivar la decisión en el interés del menor concretado ahora y descrito en el art. 2 LO 1/1996, pueda resultar bastante para entender cumplida esta exigencia.

A este respecto, el TEDH también ha considerado oportuno indicar cómo «la experiencia demuestra la imposibilidad de llegar a una precisión absoluta y muchas leyes tanto por la necesidad de evitar una rigidez excesiva como para adaptarse a la variación de las circunstancias se ven obligadas a emplear expresiones más o menos vagas» ${ }^{109}$. Por eso mismo, estima que «las circunstancias que pueden exigir el hacerse cargo de un niño o influir en la ejecución de esta medida son tan variables que sería difícil redactar una ley capaz de abarcar todas las posibilidades» y, por ejemplo, "limitar la facultad de intervención de la Administración al caso en que el niño haya sufrido ya un daño suscitaría el peligro de debilitar la protección que necesita» ${ }^{110}$.

107 Véanse SSTEDH de 25 de junio de 1996 (TEDH 1996, 29) — asunto Amuur contra Francia-, y 11 de junio de 2009 —asunto S.D. contra Grecia- (TEDH 2009, 69). Por tanto, se «exige que toda ley ha de ser lo suficientemente precisa como para permitir al ciudadano, en su caso, con el asesoramiento apropiado prever, hasta un grado razonable en las circunstancias de la causa, las consecuencias que pueden derivar de un acto determinado» [STEDH de 28 de marzo de 2000 —asunto Baranowski contra Polonia- (TEDH 2000, 107)]. Ahora bien, «la ley que confiere una facultad discrecional no falta por esto al requisito de previsibilidad si precisa su alcance y la manera de utilizarla con suficiente claridad teniendo en cuenta la legítima finalidad perseguida para proporcionar al individuo la adecuada protección contra una injerencia injusta [STEDH 24.11.1986 — asunto Gillow contra Reino Unido- (TEDH 1986, 15)].

108 STEDH 24.3.1988 —asunto Olsson contra Suecia- (TEDH 1988, 2).

109 STEDH 24.3.1988 — asunto Olsson contra Suecia- (TEDH 1988, 2).

110 SSTEDH 24.3.1988 —asunto Olsson contra Suecia- (TEDH 1988, 2); 26.5.2009 —asunto Amanalachioai contra Rumanía- (TEDH 2009, 59). 
Asimismo, siempre cabría sostener que, en última instancia, la garantía contra las injerencias arbitrarias residiría en la autoridad judicial, quien estaría autorizada para supervisar el alcance del ejercicio de una facultad discrecional que la ley pudiera haber otorgado a la Administración Pública ${ }^{111}$.

Sin embargo, no cabe decir lo mismo respecto a los menores sujetos al acogimiento residencial del art. 25 LO 1/1996 en atención a la inconcreción del mismo concepto legal de «problema de conducta ${ }^{112}$ » del párrafo segundo del apartado 1 de este precepto que, como es conocido, con autorización judicial, admite el ingreso de un menor en un centro donde resultarán afligidos sus derechos fundamentales ${ }^{113}$, tal y como así entendió, la STEDH 29.11.2011 —asunto A. y otros contra Bulgaria- (TEDH 2011, 101) en relación con la aplicación de la ley de lucha contra el comportamiento antisocial búlgara que preveía la privación de libertad de menores en función de comportamientos disociales no definidos con suficiente precisión en la ley para permitir a las interesados prever las consecuencias de sus actos, lo que, en opinión del Tribunal de Estrasburgo, podía dar lugar a prácticas arbitrarias ${ }^{114}$. Por este motivo, se abriría así la vía para que cupiera tachar de inconstitucional la regulación de los arts. 25 a 35 LO 1/1996.

111 STEDH 24.3.1988 —asunto Olsson contra Suecia- (TEDH 1988, 2).

$112 \mathrm{El}$ art. 25.1. LO 1/1996, en su párrafo segundo, delimita de modo harto ambigua, que en los centros a los que este precepto se refiere podrán ser ingresados, previa autorización judicial, «menores que estén en situación de guarda o tutela de la entidad pública, diagnosticados con problemas de conducta, que presenten conductas disruptivas o disociales recurrentes, transgresoras de las normas sociales y los derechos de terceros, cuando además así esté justificado por sus necesidades de protección y determinado por una valoración psicosocial especializada». Pero, al tiempo, el art. 26.2 LO 1/1996, aclara que «no podrán ser ingresados en estos centros los menores que presenten enfermedades o trastornos mentales que requieran un tratamiento específico por parte de los servicios competentes en materia de salud mental o de atención a las personas con discapacidad». En consecuencia, si el trastorno disocial o el comportamiento antisocial no puede reputarse como una enfermedad o trastorno mental, queda la duda acerca de qué concretos menores podrán ser ingresados en estos centros, qué profesionales dictaminarán la conveniencia de su ingreso o cómo cabrá diferenciar un trastorno mental en sentido estricto respecto a la diagnosis de un problema de conducta de un menor de edad.

113 Con más detalle, véase Díez García (2010: 197-289).

114 Razonándose, además, que esa privación de libertad carecía de finalidad educativa, en cuanto a que los menores eran ingresados en centros junto a menores delincuentes. Por ese motivo, sostuvo que había existido en el caso examinado una vulneración del art. 5 CEDH. 


\section{EL PRINCIPIO DE LEGALIDAD Y LAS INJERENCIAS PÚBLICAS EN LA ESFERA DE LOS DERECHOS FUNDAMENTALES SIN AUTORIZACIÓN JUDICIAL PREVIA}

En atención al mismo principio de legalidad, cabe plantearse, al hilo del mismo art. $18 \mathrm{CE}$ que parece requerir una autorización judicial previa a la injerencia no consentida en la esfera de los derechos que este mismo precepto reconoce y garantiza, en qué medida el art. $161 \mathrm{CC}$ que, como se ha repetido, legitima a un ente administrativo para restringir, limitar o suspender o incidir en la esfera del ejercicio de tales derechos, resulta o no respetuoso con dicha norma constitucional.

De otra parte, tampoco conviene obviar que el art. 6.1 $\mathrm{CEDH}^{115}$, que garantiza el derecho de acceso a un proceso equitativo y justo ${ }^{116} \mathrm{y}$, en esa medida también, el mismo art. $24 \mathrm{CE}$, pueden ser invocados por «todo aquel que, considerando ilegal una injerencia en el ejercicio de uno de sus derechos (de carácter civil), se queje de no haber tenido la ocasión de someter dicho litigio a un tribunal que responda a las exigencias» que dicho precepto establece ${ }^{117}$.

Hay que tener en cuenta que, de una parte, desde la perspectiva estricta de las actuaciones penales, el Tribunal Constitucional ${ }^{118}$ ha venido entendien-

115 Conforme al primer inciso de este precepto, «toda persona tiene derecho a que su causa sea oída equitativa, públicamente y dentro de un plazo razonable, por un tribunal independiente e imparcial, establecido por la ley, que decidirá los litigios sobre sus derechos y obligaciones de carácter civil o sobre el fundamento de cualquier acusación en materia penal dirigida contra ella».

116 El TEDH considera que el proceso de toma de decisiones derivado de las medidas de injerencia en el ámbito de los derechos reconocidos en el art. $8 \mathrm{CEDH}$ ha de ser equitativo y respetuoso con los intereses protegidos por esta disposición. Véanse así, SSTEDH 17.1.2012 —asunto Kopf and Liberda contra Austria- (JUR 2012, 14910); 3.5.2012 —asunto Ilker Ensar Uyanik contra Turquía - (TEDH 2012, 43); 8.1.2013 —asunto Qama v. contra Albania— (TEDH, 2013, 3); 3.6.2014 —asunto López Guió contra Eslovaquia- (TEDH 2014, 39); 16.7.2015 — asunto Akinnibosun contra Italia- (JUR 2015, 185807); 27.1.2015 —asunto Paradiso y Campanelli contra Italia- (TEDH 2015, 17); 22.10.2015 —asunto Jovanovic contra Suecia- (JUR 2015, 246772); 28.4.2016 —asunto Cincimino contra Italia- (JUR 2016, 85031).

117 SSTEDH 23.6.1981 —asunto Le Compte, Van Leuven y De Meyere contra Bélgica- (TEDH, 1981, 2) y 10.5.2001 — asunto T.P. y K.M. contra Reino Unido(TEDH 2001, 331).

118 Véanse así, por ejemplo, respecto a los análisis de ADN no ordenados judicialmente, las SSTC 199/2013, de 5 de diciembre (RTC 2013, 199) y 23/2014, de 13 de febrero (RTC 2014, 23). Respecto al secreto de las comunicaciones, véase STC 173/2011, de 7 de noviembre (RTC 2011, 173). 
do, no obstante la dicción de los apartados 2 y 3 art. $18 \mathrm{CE}$, que, como es sabido, exigen una resolución judicial previa para autorizar una intromisión no consentida en la esfera de los derechos que este precepto constitucional reconoce y garantiza ${ }^{119}$, y que si bien el criterio general es que únicamente pueden llevarse a cabo injerencias en el ámbito de este derecho fundamental mediante resolución judicial motivada ${ }^{120}$, esta regla admite excepciones cuando concurran motivos justificados para una intervención no judicial inmediata $^{121}$, siempre que dicha actuación se realice con respeto al principio de proporcionalidad. Por tanto, razones de urgencia y de necesidad, para el máximo intérprete constitucional, pueden resultar suficientes para justificar una intrusión en el ámbito de los derechos del art. $18 \mathrm{CE}$ sin la previa autorización judicial siempre que ex post resulte posible fiscalizar en vía jurisdiccional los presupuestos habilitantes de esa intervención ${ }^{122}$ y su proporcionalidad ${ }^{123}$.

En esa medida y haciendo traslación de estas consideraciones al ámbito del art. 161 CC, cabría entender que la injerencia de la entidad pública que la ley autoriza en el ámbito de los derechos reconocidos en el art. $18 \mathrm{CE}$, no resultaría inconstitucional, en cuanto que razones de urgencia y de necesidad en la tutela adecuada del interés del menor pueden exigir adoptar una decisión — que ha de ser proporcionada- como puede ser la restricción o la suspensión de sus relaciones con su núcleo familiar de procedencia.

Además, en el sistema actual de protección del menor, cabría afirmar que la autoridad judicial puede tener la oportunidad de fiscalizar la necesidad y proporcionalidad de la decisión administrativa que se hubiera adoptado, pues, además de que los interesados (incluido el propio menor) puedan recurrir judicialmente el acuerdo que la entidad pública hubiera adoptado respecto al régimen de las visitas (art. 780 LEC), no existiría imposibilidad alguna para

119 Téngase en cuenta que la resolución judicial es exigida expresamente en los apartados 2 y 3 de ese art. 18 CE.

120 SSTC 207/1996, de 16 de diciembre (RTC 1996, 207); 25/2005, de 14 de febrero (RTC 2005, 25); 233/2005, de 26 de septiembre (RTC 2005, 233).

121 STC 70/2002, de 3 de abril (RTC 2002, 70).

122 Tal y como expresa la STC 23/2014, de 13 de febrero (RTC 2014, 23 ), cabe admitir intrusiones en el derecho de la intimidad sin la preceptiva autorización judicial en casos de urgencia, siempre que la «medida adoptada sea susceptible de conseguir el objetivo propuesto (juicio de idoneidad); necesaria, en el sentido de que no exista otra medida más moderada para la consecución de tal propósito con igual eficacia (juicio de necesidad); $y$, finalmente, que sea ponderada o equilibrada, por derivarse de ella más beneficios o ventajas para el interés general que perjuicios sobre otros bienes o valores en conflicto (juicio de proporcionalidad en sentido estricto)».

123 Véase así expresamente, STC 173/2011, de 7 de noviembre (RTC 2011, 173). 
que pudieran solicitar en cualquier momento que el juez revisara dicha resolución (arts. 158 y 216 CC) o para que pudieran activar la intervención del Ministerio Fiscal [cfr. arts. 10.2.b) y 21 bis.1g) LO 1/1996) o de la propia entidad pública a fin de que se modifique el régimen de las visitas o de las comunicaciones. La única limitación explícita en la ley, para progenitores y tutores, sería la temporal de acogerse una interpretación estricta del párrafo tercero del art. 172.2 $\mathrm{CC}^{124}$; interpretación que debería desecharse por suponer, además de una privación encubierta de la patria potestad (o una remoción de la tutela) sin un previo proceso judicial con contravención del art. $170 \mathrm{CC}^{125}$ (o del art.

124 Téngase en cuenta que, conforme al párrafo tercero del art. 172.2 CC, transcurrido el plazo de dos años desde la notificación de la resolución de la declaración de desamparo, los progenitores no privados de la patria potestad o los tutores, decaen en su derecho de solicitud o de oposición a las decisiones o medidas que se adopten para la protección del menor. No obstante, se admite que puedan facilitar información a la entidad pública y al Ministerio Fiscal sobre cualquier cambio de las circunstancias que dieron lugar al desamparo. Por tanto, vencido el plazo de los dos años, esos padres o ese tutor carecerían de legitimación para pretender una modificación de las medidas acordadas por la entidad pública. En consecuencia, se les estaría denegando el acceso a la jurisdicción para hacer valer sus derechos e intereses legítimos; derechos e intereses que ese mismo art. $172 \mathrm{CC}$, en su apartado 7, reputa legítimos, en la medida en que se les posibilita, no obstante, facilitar información a la entidad pública o al Ministerio Fiscal. Por tanto, hay que reputar que semejante previsión resulta contraria al art. $24 \mathrm{CE}$ y, en esa medida, inconstitucional.

Durante la tramitación parlamentaria de la Ley 26/2015, solo un grupo parlamentario, Izquierda Plural, planteó una enmienda al art. 172. La enmienda 42 apostaba por la supresión de este apartado del precepto. Su justificación fue la siguiente: «En el apartado 2 se limita la posibilidad de que los padres impugnen la tutela automática de la Administración a dos años. La intencionalidad de ese apartado probablemente sea que si no se han preocupado durante dos años, es que no se merecen el ejercicio de la patria potestad. A nuestro juicio es excesivo, e incluso pudiera ser contrario a la constitución por limitar el derecho a la tutela judicial efectiva de un derecho fundamental. No puede ser un plazo de caducidad como la impugnación de una servidumbre de paso porque en estos casos hay otros valores en juego y otras circunstancias. A nuestro juicio los progenitores siempre podrán impugnar las medidas de la Administración. Cuestión distinta es que en el juicio se acredite la falta de interés o cualquier otra cuestión que dé lugar a la desestimación de sus pretensiones» (BOCG, Congreso, 131-3, 12 de mayo de 2015, pág. 23). El Grupo Mixto reprodujo en el Senado el sentido de esta enmienda. Véase enmienda 23. BOCG, Senado, 550, 26 de junio de 2015, pág. 56.

125 Véase en ese sentido, Pérez Álvarez (2011: 863). Téngase en cuenta que la Ley 26/2015 ha agravado la posición de los progenitores no privados de la patria potestad, puesto que, ahora, el art. 177.2.2 ${ }^{\circ} \mathrm{CC}$ considera inexigibles los asentimientos a la adopción del menor de sus padres cuando éstos estuvieran suspendidos en el ejercicio de la patria potestad - lo 
248 CC), una clara restricción de los derechos del art. 24 CE en su vertiente de acceso a la jurisdicción.

Pero es que, de otra parte, el TEDH se ha manifestado a favor de la injerencia de la Administración, en detrimento de la autoridad judicial, cuando de lo que se trata es de proteger el interés del menor, no obstante la dicción de los arts. 6.1 y 8.1 TEDH $^{126}$.

Así, ha llegado a afirmar que en un campo tan delicado como es el derecho de familia, buenas razones pueden abogar por entender que el acceso a la jurisdicción se materialice a favor de un órgano jurisdiccional cuya composición o procedimientos no sean los de un tribunal de tipo clásico ${ }^{127}$.

En particular, ha considerado, en la S. 8.7.1987 —asunto O. contra Reino Unido- (TEDH 1987, 14), que la decisión legislativa de «dejar el tema de las visitas a discreción de la autoridad local mejor que a los Tribunales», ante la necesidad de adoptar decisiones de urgencia y en atención al número de niños atendidos por los servicios locales y a la especialización de los profesionales que asisten a los menores, a pesar de reconocerse que «esta es un área en la que resulta esencial asegurar que los derechos de los padres se protegen de acuerdo con el artículo 6.1 $\mathrm{CEDH}^{128}$ ", no contraviene el tenor de este último precepto, puesto que este «no requiere que todas las decisiones sobre visitas sean tomadas por los tribunales sino solo que tengan poder para determinar cualesquiera disputas sustanciales que pudieran surgir». No obstante, se ha de reconocer a los interesados la posibilidad de que la decisión que se adopte pueda ser recurrida ante

que, como es conocido, es consecuencia ya de la declaración de desamparo ex art. 172.1 CC—y hubieran transcurrido dos años desde la notificación de dicha declaración.

126 Por ejemplo, en la S. 25.9.2008 —asunto K.T. contra Noruega— (TEDH 2008, 65), el TEDH afirma que «el derecho para un progenitor a incoar un procedimiento judicial respecto a las investigaciones sobre el cuidado de su hijo podría fácilmente debilitar la capacidad de los servicios de protección del menor para desempeñar sus funciones de forma efectiva. Tal derecho iría, por tanto, en detrimento de los menores que viven en condiciones inaceptables». Incluso en la STEDH 24.3.1988 —asunto Olsson contra Suecia- (TEDH 1988, 2) se estima que, con determinadas garantías, debe reputarse «razonable y aceptable a los efectos del art. 8 el alcance de la facultad discrecional que las leyes conceden a la Administración Pública» en orden a la protección de los menores.

127 STEDH 24.2.1995 — asunto McMichael contra Reino Unido- (TEDH 1995, 9).

128 De ahí que afirme expresamente que, "la existencia de un poder, por parte de la autoridad de decidir la limitación o incluso la supresión de las visitas de un padre a su hijo no significa necesariamente, en opinión del Tribunal, la desaparición de todo derecho paterno referente a las visitas una vez que se ha tomado una de las medidas en cuestión». Por tanto, incluso después de ser dictadas las ordenanzas de asistencia, el demandante puede reivindicar un derecho de visitar a sus hijos. 
los órganos jurisdiccionales, pues solo así se ofrecen garantías «contra el ejercicio por la autoridad de su discrecionalidad de forma inadecuada", pero siempre que la decisión de la autoridad administrativa «sea revisada por un tribunal que tenga jurisdicción para examinar el fondo del asunto» ${ }^{129}$.

Este modelo puede reputarse además conforme con las previsiones de las Directrices sobre Cuidados Alternativo de Niños (ONU, 2010) ${ }^{130}$, que no requieren una autorización judicial previa para que un menor sea separado de sus padres o de las personas que ejercen responsabilidades parentales, aunque exijan que se reconozca la posibilidad de una revisión judicial de la medida acordada.

No obstante, el esquema puede resultar inconveniente para los miembros de la familia de origen del menor, pues ahora, con la reforma de 2015, son ellos quienes deben adoptar la iniciativa y la carga procesal, lo que, en atención a la situación socioeconómica que suele rodearles y a pesar de que este art. 161 les reconoce su derecho de audiencia en el procedimiento administrativo, podría llegarles a ocasionar una situación de indefensión material fundamentalmente porque este art. 161 omite realizar cualquier consideración a la necesidad de dotar de asistencia legal a estos interesados o sobre su derecho a ser informados sobre las vías de oposición a la decisión de la Administración ${ }^{131}$. Además, también ha de advertirse que la resolución que adopte la entidad pública no necesariamente trascenderá a la fiscalización judicial si los interesados o si el Ministerio Fiscal no la activan. Por este motivo, el sistema resultaría mucho más respetuoso con los derechos de los afectados si la intervención judicial resultara obligada a fin de ratificar una resolución adoptada de modo cautelar por la Administración.

Aun así, de todos modos conviene detallar entonces hasta qué punto los derechos que del art. $24 \mathrm{CE}$ resultan o no respetados en el mismo procedimiento administrativo que conduce a una injerencia en la vida privada y familiar de estos interesados.

${ }^{129}$ Lo que, al parecer, no se contemplaba en ese supuesto por la legislación interna aplicable, por lo que, finalmente, apreció el TEDH una vulneración del art. 6.1 CEDH.

130 OB 14, \$ 46: «Toda decisión sobre la remoción de la guarda de un niño contra la voluntad de sus padres debe ser adoptada por la autoridad competente, de conformidad con las leyes y procedimientos aplicables y estar sujeta a revisión judicial, garantizándose a los padres el derecho de recurso y el acceso a asistencia letrada adecuada». (La cursiva es mía).

131 El $\$ 65$ de las Directrices (ONU) sobre cuidado alternativo de niños (2009) señala lo siguiente: «Los Estados deberían velar por que todo niño cuyo acogimiento alternativo haya sido resuelto por un tribunal judicial o cuasi judicial debidamente constituido o por un órgano administrativo u otro órgano competente, así como sus padres u otras personas que ejerzan las funciones parentales, tengan la posibilidad de ejercitar ante un tribunal de justicia su oposición a la resolución de acogimiento adoptada, sean informados de su derecho a ejercitar tal oposición y reciban asistencia para ello». (La cursiva es mía). 


\section{LAS GARANTÍAS PROCESALES DE LOS INTERESADOS EN EL PROCEDIMIENTO ANTE LA ENTIDAD PÚBLICA}

Incluso en vía administrativa resulta obligado que se respeten las garantías procedimentales implícitas en el art. $24 \mathrm{CE}^{132}$ o en el art. $6.1 \mathrm{CEDH}^{133}$. De este modo, ha de asegurarse que los interesados, incluido el propio menor, sean oídos en el procedimiento. Exigencia esta que explícitamente refleja el art. $161 \mathrm{CC}$, al obligar a la entidad pública a dar audiencia, antes de adoptar su decisión, a los afectados y al menor ${ }^{134}$ si tuviera suficiente madurez ${ }^{135} \mathrm{y}$, en todo caso, si fuera mayor de 12 años $^{136}$.

132 Recuérdese que el TC [véanse por ejemplo, SSTC 292/2005, de 10 de noviembre (RTC 2005, 292) y 217/2009, de 14 de diciembre (RTC 2009, 217)] considera que, cuando la cuestión de fondo afecta al interés de un menor, resulta de aplicación un "canon reforzado" de la tutela judicial efectiva respecto a otro tipo de asuntos.

133 Cfr. STEDH 24.2.1995 — asunto McMichael contra Reino Unido- (TEDH 1995, 9). Cfr., asimismo, arts. 35, 79, 84 y 85 de la Ley 30/1992 y arts. 53, 76 y 82 de la Ley $39 / 2015$.

${ }^{134}$ Con carácter general, tanto en el ámbito familiar, cuanto en la órbita de cualquier procedimiento administrativo, judicial o de mediación en que esté afectado y que conduzca a una decisión que incida en su esfera personal, familiar o social, el menor tiene derecho a ser oído y a ser escuchado (art. 9.1 LO 1/1996, en redacción dada por el art. 1.4 de la LO 8/2015). Este derecho de los menores aparece también recogido en el art. 12 de la Convención de Naciones Unidas de los Derechos del niño de 20 de noviembre de 1989 (Instrumento de ratificación de 30 de noviembre de 1990); en el art. 2 del Protocolo facultativo de la Convención sobre los Derechos del Niño relativo a un procedimiento de comunicaciones, hecho en Nueva York el 19 de diciembre de 2011 (Instrumento de ratificación BOE, 27, 31 de enero de 2014); en el art. 24.1 de la Carta de los derechos fundamentales de la Unión Europea -e íntegramente reproducida en el art. 2 LO 1/2008, de 30 de junio por la que se autoriza la ratificación por España del Tratado de Lisboa-, así como en el art. 7.3 de la Convención sobre los Derechos de las Personas con Discapacidad, hecho en Nueva York el 13 de diciembre de 2006 (Instrumento de ratificación, BOE, 96, 21 de abril de 2008). Sin embargo, este es un derecho del menor, no una obligación.

135 El juicio de madurez debe ser realizado por personal especializado teniendo en cuenta tanto el desarrollo evolutivo del menor como su capacidad para comprender y evaluar el asunto concreto a tratar en cada caso [véase Comité de los Derechos del Niño (2009).

Conviene tener en cuenta que, en el contexto del art. 12 de la Convención de Derechos del Niño, el «estar en condiciones de formarse un juicio propio» es presupuesto de su derecho a ser escuchado $(\mathrm{OB} 12, \$ 20)$, pero el menor no tiene la carga de probar primero esa madurez a la hora de expresar su opinión. Ello no quiere decir que no 
No cabe duda alguna de que el derecho del menor a ser oído y escucha$\mathrm{do}^{137}$ en el ámbito del procedimiento integra su derecho a la tutela judicial efectiva, tal y como así ha entendido nuestro Tribunal Constitucional ${ }^{138}$. Pero es que, además, el art. 2.5 a) de la LO 1/1996 le reconoce ahora, tras la LO 8/2015, el derecho a ser informado, oído y escuchado ${ }^{139}$, y a participar en el proceso del que resulte una medida en su interés. Pues bien, para emitir su juicio fundado, el menor tiene que recibir toda la información pertinente, incluyendo las «posibles consecuencias de actuar conforme a esa opinión y de las posibles consecuencias de cualquier resolución $»^{140}$. Para una adecuada

se deba oír al menor de 12 años o no maduro, pues su exploración deberá adaptarse a sus circunstancias, sino que, solo con madurez, la opinión del menor deberá ser necesariamente tenida en cuenta $(\mathrm{OB} 12, \$ 28$ y 44$)$, ya que esa valoración debe adaptarse a la edad y madurez del niño, sin discriminación alguna por razón de la edad (OB $12, \$ 29)$.

136 Véase también, art. 154.IV CC y art. 9.2 LO 1/1996 y OB 14, $\$$ 44. Con esta previsión, el legislador español incumple las previsiones del Comité de los Derechos del Niño que, en su observación general 12 (2009), \$21, desaconseja a los Estados partes que introduzcan por ley o en la práctica límites de edad que restrinjan el derecho del niño a ser escuchado en todos los asuntos que lo afectan. El Defensor del Pueblo (2014: 39-41) recomendaba eliminar los criterios de edad respecto del derecho del niño a ser escuchado, sustituyéndolo por la presunción de la capacidad del menor para formarse un juicio propio.

137 El art. 211-6.2 del Código Civil de Cataluña, en cambio, habla del derecho del menor a «ser informado y escuchado».

138 Véanse por ejemplo, SSTC 124/2002, de 20 de mayo (RTC 2002, 124); 71/2004, de 19 de abril (RTC 2004, 71); 152/2005, de 6 de junio (RTC 2005, 152)); 153/2005, de 6 de junio (RTC 2005, 153); 17/2006, de 30 de enero (RTC 2006, 17); 22/2008, de 31 de enero (RTC 2008, 22); 183/2008, de 22 de diciembre (RTC 2007, 183); 163/2009, de 29 de junio (RTC 2009, 163). No obstante, en el ATC 47/2009, de 13 de febrero (RTC 2009, 47 Auto) se reputó que la ausencia de exploración a un menor bajo acogimiento familiar en un procedimiento del art. $158 \mathrm{CC}$ por el que se adoptaban medidas provisionales en el marco de un proceso de ejecución de una resolución judicial que ordenaba su retorno con su familia biológica, no había ocasionado una lesión a su derecho a la tutela judicial efectiva, en atención a la necesidad de adoptar una medida que se reputaba urgente y «ante los riesgos para la integridad moral de la menor que se intentaban conjurar, y dado que el hecho de que la menor convivía con aquéllos frente a quienes se la quería proteger». Véase Marín López (2005: 165 y ss. y 2009: 249 y ss.).

139 Puede parecer una redundancia el exigir el oír y, además, el requerir el escuchar. Pero cabe entender que escuchar es algo más que oír, tal y como expresa Ruiz-Rico Ruiz Moron (2016: 3).

${ }^{140}$ Véase el art. 3 del Convenio europeo sobre el Ejercicio de los Derechos de los Niños. 
información se precisa de personas con formación y habilidades profesionales específicas $^{141}$ en el trato a los menores [(art. 2.5.b) LO 1/1996]. De otra parte, la adecuada defensa de sus intereses en el proceso exige poder contar con asistencia jurídica ${ }^{142}$ [arts. 2.5.c) y 10.2.e) LO 1/1996] ${ }^{143}$, aunque pueda intervenir por sí mismo en el expediente administrativo [art. 30 Ley 30/1992 y art. 3 b) Ley 39/2015]. Además, ha de poder pedir la designación de un defensor judicial cuando exista un conflicto de interés con sus propios representantes legales [art. 2.5.c) y 10.2.e) LO $1 / 996^{144}$ en relación con el art. 27 LJV] ${ }^{145} \mathrm{e}$ incluso podría instar en vía administrativa el nombramiento de un portavoz que le asista a la hora de expresar su opinión (art. 9 LO 1/1996). Pero también la entidad pública habrá de tener en cuenta su criterio («teniéndose en cuenta sus opiniones») ${ }^{146}$, de acuerdo con su edad y su madurez ${ }^{147}$.

Por tanto, no cabe pensar que el eventual derecho de audiencia del menor pueda quedar reducido a un mero trámite formal del procedimiento cuando este tenga madurez suficiente. La opinión del menor es uno de esos criterios generales con los que cabe interpretar y aplicar su mismo interés ${ }^{148}$ (art.2.2 b. LO 1/1996), aunque dicho criterio deba ser ponderado con otros elementos

141 Cfr. OB 14, \$94

${ }^{142}$ En la OB 14, $\$ 96$ se hace notar que «el niño necesitará representación letrada adecuada cuando los tribunales y órganos equivalentes hayan de evaluar y determinar oficialmente su interés superior. En particular, cuando se someta a un niño a un procedimiento judicial o administrativo que conlleve la determinación de su interés superior, el niño debe disponer de representación letrada, además de un curador o representante de su opinión, cuando pueda haber un conflicto entre las partes en la decisión» (La cursiva es mía).

143 Véase art. 102 de la Ley 12/2008, de 3 de julio, de protección integral de la infancia y la adolescencia de la Comunitat Valenciana.

144 Prevista para la impugnación judicial por el adolescente de la resolución administrativa de desamparo por el art. 113.2 de la Ley 14/2010, de 27 de mayo, de normas reguladoras de los derechos y oportunidades de la infancia y la adolescencia de Cataluña.

145 Véanse arts. 4 y 9 del Convenio Europeo sobre el Ejercicio de los Derechos de los Niños.

146 Véase OB 12, $\$ 15$.

147 OB 14, $\$$ 44: «Cuando estén en juego el interés superior del niño y su derecho a ser escuchado, debe tenerse en cuenta la evolución de las facultades del niño (art. 5). El Comité ya ha determinado que cuantas más cosas sepa, haya experimentado y comprenda el niño, más deben los padres, tutores u otras personas legalmente responsables del niño transformar la dirección y orientación en recordatorios y consejos y, más adelante, en un intercambio en pie de igualdad. Del mismo modo, a medida que el niño madura, sus opiniones deberán tener cada vez más peso en la evaluación de su interés superior».

148 Para un supuesto en que resulta determinante esa opinión, incluso frente a las conclusiones del estudio del equipo psicosocial, véase STS 13.2.2015 (RJ 2015, 681). 
generales; entre ellos, su edad y su madurez (art. 2.3.a. LO 1/1996), pero, lógicamente, no permitirá fundar exclusivamente la decisión en esa opinión sin otros elementos de prueba de su interés ${ }^{149}$. En esa medida, cualquier decisión en su interés que resulte contraria a esa opinión requerirá de una especial motivación en la que se tengan en cuenta y se ponderen cualquiera de los elementos y criterios generales contenidos en los apartados 2 y 3 del art. 2 LO $1 / 1996^{150}$. Téngase en cuenta, además, a este respecto, que el resultado de la audiencia al menor y su valoración deberá incluirse en la correspondiente resolución que le pudiera afectar ${ }^{151}$. Incluso esa opinión puede resultar una barrera infranqueable para cualquier decisión contraria cuando el menor tenga madurez suficiente y/o sea mayor de 12 años $^{152}$ porque a partir de ese momento, el legislador le confiere autonomía para decidir sobre su vida privada y familiar, tal y como demuestra el que se le autorice consentir su propio acogimiento (art. 173.2 CC).

Esa audiencia, que adquiere carácter preferente, ha de realizarse en las condiciones aptas para preservar su intimidad y debe adaptarse a las propias condiciones del menor ${ }^{153}$, por lo que deberá emplearse un lenguaje accesible para él. El menor puede contar con la asistencia de personal especializado o, su caso, puede intervenir asistido de intérprete. Pero deberá ser informado del alcance de las preguntas y de las consecuencias de sus respuestas y, por supuesto, se deberán respetar todas sus garantías procesales (art. 9.1, párrafo segundo, en relación con el art. 2.5 LO 1/1996) ${ }^{154}$. Esa opinión podrá ser emitida por el menor incluso mediante lenguaje no verbal (art. 9.2.II LO 1/1996) — recuérdese que la audiencia debe adaptarse a las circunstancias del propio menor y que se proscribe todo tipo de discriminación por razón de su discapa-

149 Véase STEDH 14.3.2013 —asunto B.B. y F.B. contra Alemania- (TEDH 2013, 30).

${ }^{150}$ Véase sobre el proceso de evaluación del interés del menor, Guilarte Martín-Calero (2016: 119-126).

151 Véase OB 12, \$ 45.

152 Véase STEDH 8.7.2003 — asunto Sommerfeld contra Alemania- (JUR 2003, 162887). Para un supuesto en que son los menores, en acogimiento residencial, quienes solicitan la suspensión de las visitas de su progenitora, véase SAP Barcelona 25.7.2012 (JUR 2012, 394425).

153 El entorno en que se realice la escucha debe ser amigable (OB 12, $₫ 34$ ). El acto ha de ser confidencial y ha de adoptar la forma de una conversación antes que de un interrogatorio o escrutinio (OB 12, $\$ 42$ y 43).

154 Véase OB 12, $\$ 41$. 
cidad $^{155}$, edad ${ }^{156}$ o cualquier otra circunstancia (art. 9.1 LO 1/1996)—. Para emitir su opinión con conocimiento de causa y que resulte relevante, se debe proporcionar al menor la información hábil que le permita el ejercicio de este derecho en un lenguaje comprensible, en formatos accesibles y adaptados a sus circunstancias (art. 9.1 LO 1/1996).

Iguales o similares cautelas procesales deberán observarse respecto a los demás afectados por la decisión de la entidad pública ${ }^{157}$. Además de darles audiencia ${ }^{158}$, esa entidad habrá de respetar los principios de contradicción y de defensa ${ }^{159}$, por lo que habrá de ser atenta a las propuestas de la práctica de la prueba que estos formulen (que, obviamente, en su caso, podrá admitir o

155 La exposición de motivos de la LO 8/2015 estima que «no puede existir ningún tipo de discriminación en el ejercicio de este derecho por razón de su discapacidad», en línea con lo dispuesto en el art. 7.3 de la Convención de Naciones Unidas sobre los derechos de las personas con discapacidad de 13 de diciembre de 2006 (Instrumento de ratificación, BOE, 96, de 21 de abril de 2008).

156 Véase OB 12, \$ 21.

157 El TEDH considera que, a pesar de que el art. 8 CEDH no implica ninguna condición explícita de procedimiento, el proceso de toma de decisiones ligado a las medidas de injerencia debe ser equitativo, por lo que los progenitores de un menor han de jugar un papel lo suficientemente grande en el procedimiento como para otorgarle la protección de sus intereses. En caso contrario, existiría un incumplimiento del respeto a la vida privada y familiar y la injerencia resultante de la decisión no podría considerarse necesaria en el sentido del art. 8.2 CEDH. Véanse así, SSTEDH 27.1.2015 —asunto Paradiso y Campanelli contra Italia- (TEDH 2015, 17). 28.4.2016 —asunto Cincimino contra Italia- (JUR 2016, 85031).

158 Sin embargo, por ejemplo, ante una sospecha de abusos sexuales a un niño por parte de su progenitor, se ha de proceder de forma inmediata, por lo que no resultaría viable el avisarle previamente de una decisión de alejamiento del menor pues esa advertencia podría exponer al menor al riesgo de eventuales presiones de su padre durante la instrucción del correspondiente procedimiento penal [véase así, STEDH 24.2.2009 —asunto Errico contra Italia- (TEDH 2009, 26)].

159 Por ejemplo, no cabrá denegar la entidad pública el acceso completo de los interesados a los informes incorporados al expediente. Véase así, para un caso en que se deniega a un progenitor el acceso a un informe de los servicios sociales cuando se había suspendido provisionalmente su derecho de visita con su hijo y en el que se reputa que dicha denegación determina un incumplimiento de las obligaciones positivas del art. $8 \mathrm{CEDH}$, STEDH 15.10.2009 —asunto Tsourlakis contra Grecia- (TEDH 2009, 108). Y es que el TEDH reputa que «sobre las autoridades recae la obligación positiva de ofrecer al demandante un procedimiento efectivo y accesible que le permita acceder al conjunto de informaciones pertinentes y apropiadas». 
denegar fundadamente) ${ }^{160}$ — cfr. arts. 79 a 82, 84 y 85, Ley 30/1992, y arts. 76, 77, 78, 82, Ley 39/2015-. Asimismo, resultaría conveniente que se les proveyera de asistencia letrada ${ }^{161}$, aunque esta no sea requerida para defender sus derechos e intereses en vía administrativa [cfr. arts. 85.2 Ley 30/1992 y 53.1.g), Ley 39/2015], para evitar así la denunciada y reprochada indefensión material que suele rodear a las familias de origen de menores tutelados por la entidad pública en los procedimientos administrativos que esta incoa ${ }^{162}$ y tal y como así se requiere en las Directrices Alternativas de Cuidado de Niños [(2009), \$ 65].

${ }^{160}$ En el caso contemplado en la STEDH 13.7.2000 — asunto Elsholz contra Alemania(TEDH 2000, 152), considera el TEDH que existió vulneración del art. 8.1 CEDH por el hecho de que los tribunales alemanes hubiera denegado la práctica de un informe pericial psicológico que acreditara el perjuicio de las visitas de un progenitor a sus hijos menores. Igualmente, en el supuesto examinado por la STEDH 28.4.2016 —asunto Cincimino contra Italia- (JUR 2016, 85031) se entiende que hubo vulneración de las garantías procesales inherentes al art. $8 \mathrm{CEDH}$ por el hecho de que los jueces italianos motivarán su decisión de privar de la potestad a una madre sobre una hija en función de la inexistencia de todo contacto durante siete años entre ellas. Suspensión de contacto fundado en un dictamen psiquiátrico que apreciaba una trastorno de personalidad de la madre. Pues bien, pese a la petición expresa de la progenitora, el Tribunal decidió sin solicitar nuevo informe sobre la situación actual de la madre y del hijo. Por este motivo, el TEDH estimó que el proceso decisional no había respetado las exigencias procesales del art. $8 \mathrm{CEDH}$.

161 Téngase en cuenta que, a juicio del TEDH, «el artículo 6.1 puede en ocasiones obligar a un Estado a proveer de esa asistencia jurídica cuando se demuestre el carácter indispensable de esta para un acceso efectivo ante los tribunales, ya sea porque sea legalmente exigida la asistencia de letrado, como ocurre en los ordenamientos internos de algunos de los Estados contratantes para determinados tipos de procesos, ya por la complejidad del procedimiento o del caso" ([STEDH 9.10.1979 — asunto Airey contra Irlanda— (TEDH 1979, 3)]. En el caso examinado por la STEDH 16.7.2009 — asunto Nenov contra Bulgaria(TEDH, 2009, 79), se reputó que el hecho de no haberse beneficiado de asistencia jurídica un progenitor que demandaba una modificación del régimen de visitas podía reputarse contraria al art. 6.1 CEDH, por cuanto le había privado de la posibilidad de defender eficazmente su causa, atendidas sus circunstancias personales, y porque esta circunstancia había supuesto una desigualdad de armas inaceptable, en la medida que la madre de los menores contaba con dicha asistencia letrada. Véase también STEDH de 29 de febrero de 1988 (TEDH 1988, 5) —asunto Buoamar contra Bélgica-.

162 El Defensor del Pueblo (2014: 25-26) advertía cómo el trabajo de los servicios sociales se desarrolla, en la mayor parte de las ocasiones, sin formalidades administrativas, por lo que los progenitores suelen desconocer la trascendencia y posibles consecuencias que puede tener el incumplimiento del plan propuesto por los servicios sociales. «Ello puede implicar en el origen del conflicto situaciones de indefinición e inseguridad jurídica e, incluso, de indefensión». 
Asimismo, y, aplicando mutatis mutandis lo dispuesto en el art. 172.1 CC, la resolución debe ser notificada por la entidad pública a los progenitores, tutores o guardadores del menor y a este si tuviere suficiente madurez y/o fuera mayor de 12 años (arts. 2.5 y 9 LO 1/1996). Igualmente, esta resolución también habrá de comunicarse al Ministerio Fiscal (arts. 174 y 232 CC) y al juez que hubiera constituido la tutela ordinaria (art. 216 CC y art. 50 LJV). Notificación que, de otra parte, deberá realizarse a cualquier interesado que haya comparecido en el expediente (arts. 31, 58 y 59 Ley 30/1992; arts. 4, 40 y 53 Ley 39/2015). Aparte de la información obvia de la misma aplicación de una decisión de restricción o de suspensión temporal de las visitas y de las relaciones del art. 161 CC y que, según el art. 172.1, se debe suministrar de forma clara, comprensible y en formato accesible, para garantizar el derecho de defensa de todos los interesados, se les ha de informar de las vías legales de oposición (véase. art. 89.3 Ley 30/1992) ${ }^{163}$ y de la posibilidad de acudir, en su caso, a la justicia gratuita $^{164}$.

El incumplimiento de estas garantías procesales puede ocasionar una vulneración a los derechos reconocidos en el art. $24 \mathrm{CE}$, lo que daría lugar a la nulidad de las actuaciones administrativas [art. 62.1.a) de la Ley 30/1992 y art. 47.1.a) de la Ley 39/2015], pero acatadas estas garantías procesales, la posibilidad en sí de que la entidad pública pueda injerirse en la vida privada y familiar del menor y la de sus familiares y allegados, no incumpliría las exigencias previstas en ese precepto constitucional, ni los requisitos previstos en el art. 6.1 CEDH, siempre que, a su vez, fueran cumplidos los presupuestos del art. 8.2 CEDH.

163 OB. 14, \$ 98: «Los Estados deben establecer mecanismos en el marco de sus ordenamientos jurídicos para recurrir o revisar las decisiones concernientes a los niños cuando alguna parezca no ajustarse al procedimiento oportuno de evaluación y determinación del interés superior del niño o los niños. Debería existir siempre la posibilidad de solicitar una revisión o recurrir una decisión en el plano nacional. Los mecanismos deben darse a conocer al niño, que ha de tener acceso directo a ellos o por medio de su representante jurídico, si se considera que se han incumplido las garantías procesales, los hechos no son exactos, no se ha llevado a cabo adecuadamente la evaluación del interés superior del niño o se ha concedido demasiada importancia a consideraciones contrapuestas. El órgano revisor ha de examinar todos esos aspectos».

164 Así lo propuso el Consejero de Política Social, Mujer e Inmigración de la Región de Murcia en su comparecencia, el 21 de septiembre de 2009, ante la Comisión Especial para el estudio de la problemática de la adopción nacional y otros temas afines, constituida en el Senado (BOCG, Senado, 545, 17 de noviembre de 2010, 23). En ese mismo sentido se manifiesta el Defensor del Pueblo (2014) al denunciar la carencia de información y de asistencia jurídica de las familias biológicas. 
El único obstáculo que se vislumbra en el esquema legal del art. $161 \mathrm{CC}$ para salvar cualquier escollo acerca de su constitucionalidad, vendría dada por el carácter no parcial e independiente que en este tipo de procedimientos pueda tener la entidad pública.

Recuérdese que el derecho a un proceso con todas las garantías del art. 24.2 CE o el derecho de acceso a un proceso equitativo y justo del art. 6.1 $\mathrm{CEDH}$ también comprende el derecho a un juez imparcial ${ }^{165}$. Esa imparcialidad exige que el conflicto sea decidido exclusivamente "por un tercero ajeno a las partes y a los intereses en litigio» ${ }^{166}$. Y, evidentemente, puede dudarse de esta condición en la misma entidad pública, que, en estos casos, asume la condición de juez y de parte al asumir simultáneamente la condición de tutor del menor y de decisor del conflicto en su interés. Únicamente resultaría posible salvar este eventual reproche constitucional reputando que, en estos casos, al existir un conflicto de interés, debería cesar en su representación legal del menor, por lo que habría de proveerse a un representante para ese niño y encomendar a un tercero la decisión del conflicto; o reputando que, en verdad, la tutela ex lege constituye en verdad una tutela institucional por lo que idealmente no pueden existir dicho conflictos de interés, ya que la posición de la entidad pública es la de asumir la defensa del interés objetivo del menor en concreto. Pero evidencia que, quizás, el mejor esquema para salvar esos escollos no sea el escogido por el legislador, sino cualquier otro que obvie su intervención, cuando es tutora del menor, para acordar ella misma una decisión que constituye una injerencia en los derechos fundamentales de los afectados por ella.

\section{LA MOTIVACIÓN EN INTERÉS DEL MENOR}

\section{EL INTERÉS DEL MENOR EN LA MOTIVACIÓN DE LAS RESOLUCIONES QUE PUDIERAN AFECTARLE}

Tal y como se ha indicado, el respeto al derecho a la tutela judicial efectiva del art. $24 \mathrm{CE}$ exige que la decisión que se adopte ex art. $161 \mathrm{CC}$ resulte

165 STC 39/2004, de 22 marzo (RTC 2004, 39).

166 Véanse, por ejemplo, las SSTC 5/2004, de 16 de enero (RTC 2004, 5) y 140/2004, de 13 septiembre (RTC 2004, 140): «Esta obligación de ser ajeno al litigio puede resumirse en dos reglas: primera, que el juez no puede asumir procesalmente funciones de parte; segunda, que no puede realizar actos ni mantener con las partes relaciones jurídicas o conexiones de hecho que puedan poner de manifiesto o exteriorizar una previa toma de posición anímica a su favor o en su contra». 
motivada ${ }^{167}$ y fundada precisamente en su interés ${ }^{168}$, de acuerdo con los criterios y elementos a los que se refieren, tras la LO 8/2015, los apartados 2 y 3 del art. 2 LO 1/1996 ${ }^{169}$. Por tanto, la decisión que el juez adopte al respecto, fundada en dicho interés, podrá ser discrecional en la apreciación de cuál deba ser este, pero no arbitraria ${ }^{170}$. Pero resultará insuficiente una motivación por referencia a un informe que evalúa la situación del menor emitido con un año de anterioridad y que, por tanto, no tiene en cuenta la actual situación del niño y su familia ${ }^{171}$. Como también puede reputarse falta de motivación una resolución en la que, simplemente, se acuerde la suspensión temporal de las relaciones en orden a la "gravedad de la situación»" ${ }^{172}$.

El interés del menor básicamente consiste en salvaguardar sus derechos fundamentales y garantizar el libre desarrollo de su personalidad (art. 2 LO 1/1996). En principio, cabe afirmar que el ejercicio de las visitas estará subordinado a la ausencia de todo perjuicio o de peligro de todo daño al menor (art. $158.4^{\circ}$ y 216 CC). No obstante, será la entidad pública quien tenga que acreditar la existencia o probabilidad de ese riesgo; riesgo que, en atención a las circunstancias concurrentes en el eventual conflicto de intereses, deberá ponderarse en la correspondiente resolución administrativa ${ }^{173}$.

En este orden de cosas, hay que tener en cuenta que, conforme expresara el Comité de los Derechos del Niño, en su Observación General 14, acogida por nuestro legislador, ese interés del menor es un concepto con triple fun-

167 Véase OB 14, \$97. Sobre esa necesidad de motivación, véase además, SSTC 127/2013, de 3 de junio (RTC 2013, 127). Asimismo, véanse STS 4.2.2016 (RJ 2016, 260) y ATC 47/2009, de 13 de febrero (RTC 2009, 47 Auto) y STC 138/2014, de 8 de septiembre (RTC 2014, 138). Véase sobre esta última sentencia y sobre la necesidad de motivar en interés del menor, Colás Escandón (2015: 170-174). Últimamente, véase STC 16/2016, de 1 de febrero (RTC 2016, 16).

168 Véanse, por ejemplo, SSTEDH 26.11.2013 —asunto X contra Letonia- (JUR 2013, 354045); 3.10.2014 — asunto Jeunesse contra Paises Bajos- (JUR 2014, 247419); 16.12.2014 —asunto Chbihi Loudoudi y otros contra Bélgica- (TEDH 2014, 101).

169 Sobre los criterios de determinación del interés del menor, véase Colás Escandón (2015: 160-169).

170 Rivero Hernández (1997: 163-164).

171 STSJ Galicia 27.10.2011 (RJ 2012, 2242).

172 SSTSJ Galicia 22.2.2012 (RJ 2012, 432) y 6.3.2015 (RJ 2015, 1237).

173 Rivero Hernández (1997: 180). 
cionalidad ${ }^{174}$ : es un derecho sustantivo, es un principio interpretativo $\mathrm{y}$, al tiempo, es una norma de procedimiento ${ }^{175}$.

El interés del menor se erige en un derecho sustantivo, en el sentido de que el menor tiene derecho a que su interés sea reputado como primordial cuando resulte necesario adoptar cualquier medida que pudiera afectarle, tanto en el ámbito público como privado (art. 2.1 LO 1/1996) ${ }^{176}$. De otra parte, la preferencia de ese interés — que puede ser reputado como principio general del derecho- debe guiar el proceso de interpretación de las normas (cfr. art. $1.3 \mathrm{CC})^{177}$. Pero, además, es una norma procesal, en cuanto que la evaluación y determinación del interés del menor exigen el necesario respeto a las garantías procesales ${ }^{178}$, tal y como se evidencia en el art. 2.5 de la LO 1/1996, apartado que acoge la influencia no solo de la observación general 14 del Comité de los Derechos del Niño ${ }^{179}$, sino también del Convenio Europeo sobre el Ejercicio de los Derechos de los Niños, hecho en Estrasburgo el 25 de enero de $1996^{180}$ a cuya luz debe interpretarse esta norma "procesal» (art. 10.2 CE y art. 3 LO/1996).

A la hora de concretar el interés del menor, debe tenerse presente que la redacción del art. $2 \mathrm{LO}$ 1/1996 por medio del art. 1.2 LO 8/2015, que proce-

174 OB $14, \$ 6$.

${ }^{175}$ A esta triple funcionalidad del concepto hace expresa referencia la STS 20.7.2015 (RJ 2015, 2786). Igualmente, véase Ruiz-Rico Ruiz Morón (2016:, 3).

176 Véase OB 14, \$1.

177 OB 14, \$ 12. Véanse así, SSTS 19.11.2015 (RJ 2015, 5495); 11.2.2016 (RJ 2016, 524); 19.2.2016 (RJ 2016, 924); 1.3.2016 (RJ 2016, 925); 17.3.2016 (RJ 2016, 1131); 29.3.2016 (RJ 2016, 995); 3.6.2016 (RJ 2016, 2330).

178 OB 14, \$ 6 c): «Una norma de procedimiento: siempre que se tenga que tomar una decisión que afecte a un niño en concreto, a un grupo de niños concreto o a los niños en general, el proceso de adopción de decisiones deberá incluir una estimación de las posibles repercusiones (positivas o negativas) de la decisión en el niño o los niños interesados. La evaluación y determinación del interés superior del niño requieren garantías procesales. Además, la justificación de las decisiones debe dejar patente que se ha tenido en cuenta explícitamente ese derecho. En este sentido, los Estados partes deberán explicar cómo se ha respetado este derecho en la decisión, es decir, qué se ha considerado que atendía al interés superior del niño, en qué criterios se ha basado la decisión y cómo se han ponderado los intereses del niño frente a otras consideraciones, ya se trate de cuestiones normativas generales o de casos concretos".

179 Véase OB 14, $\$ 85$ a 88

${ }^{180}$ Instrumento de ratificación BOE, 45, 21 de febrero de 2015. 
de a desarrollar y reforzar el derecho del menor a que su interés sea prioritario ${ }^{181}$, ofrece una nueva y prolija regulación de dicho interés acogiendo las recomendaciones formuladas tanto por el Comité de Derechos del Niño ${ }^{182}$ como por la Comisión Especial constituida en el Senado para el Estudio de la Problemática de la Adopción Nacional y Otros Temas Afines ${ }^{183}$, que apostaban por

181 Cierto es que, con anterioridad a esta reforma, ese mismo precepto ya afirmaba la preferencia de ese interés frente a cualquier otro interés legítimo que pudiera concurrir en lo que hacía referencia a la aplicación de esa fundamental norma legal de protección jurídica del menor. De este modo, ese interés se había erigido en un auténtico estándar jurídico con el que modular y medir toda medida que, en su protección, cupiera adoptar como así había entendido el Tribunal Supremo [(S. 31.7.2009 (RJ 2009,4581). Igualmente, véanse SSTS 21.2.2011 (RJ 2011, 2362); 6.2.2012 (RJ 2012, 4522); 17.2.2012 (RJ 2012, 3924); 27.10.2014 (RJ 2014, 5183) y 20.7.2015 (RJ 2015, 2786). Igualmente, véanse SSTS 15.10.2015 (RJ 2015, 4861) y 2.12.2015 (RJ 2016, 117)

182 Comité de los Derechos del Niño. $55^{\circ}$ período de sesiones. 13 de septiembre a 1 de octubre de 2010 Examen de los informes presentados por los Estados partes en virtud del artículo 44 de la Convención CRC/C/ESP/CO/3-4, \$ 27.

183 Se hacía notar por parte de algunos comparecientes la necesidad de fijar pautas o parámetros que permitieran determinar ese concepto jurídico indeterminado También se apostaba porque se incluyeran en la ley los criterios básicos que habrían de orientar al juzgador en una aplicación de la norma en función de las necesidades y derechos del menor siguiendo el modelo británico o que, al menos, ese interés fuera definido legalmente para evitar eventuales arbitrariedades. Incluso, se criticaba la excesiva laxitud del concepto, que le hacía demasiado vulnerable «frente al denominado biologicismo que termina primando en determinados supuestos». Véase BOCG, Senado, 545, 17 de noviembre de 2010, 13, 17 y 30. De esta forma, la Comisión, en sus conclusiones, consideraba que había que ofrecer un desarrollo legal a dicho principio a fin de posibilitar una interpretación homogénea por parte de los operadores jurídicos y concretar más dicho concepto jurídico indeterminado, por lo que la ley habría de acoger los criterios básicos que habían de orientar al juzgador en una correcta aplicación de la norma. Véase BOCG, Senado, núm. 545, 17 de noviembre de 2010, 45.

Acogiendo tales conclusiones y recomendaciones, la Proposición de Ley de actualización de la legislación sobre protección a la infancia presentada en el Congreso por el Grupo Socialista que finalmente fue rechazada, apreciando la inseguridad provocada por este concepto jurídico indeterminado, reputaba imprescindible introducir en nuestra legislación unos criterios de interpretación y aplicación de ese interés a través de una nueva redacción del art. 2 de la LO 1/1996, criterios que, sustancialmente, en poco difieren de los alumbrados después por la LO 8/2015 en su art. 2.2. Véase BOCG, Congreso, 83-1, 6 de julio de 2012. 
delimitar legalmente ${ }^{184}$ los confines de este concepto jurídico indetermina$\mathrm{do}^{185}$ introduciendo criterios básicos para su determinación ${ }^{186}$; criterios que, enunciados ahora en este precepto, siguen claramente el canon del derecho del Reino Unido (art. 1, Children Act, 1989) ${ }^{187}$, así como los elementos delimitadores de ese interés contenidos la Observación General 14 (2013) sobre el derecho del niño a que su interés superior sea una consideración primordial (art. 3, párrafo 1) que el Comité de Derechos del Niño formuló y que fue publicada con fecha de 29 de mayo de 2013.

Pues bien, a partir de la Ley 26/2015, la entidad pública (y, en su caso, el juez), para acordar cualquier restricción de las relaciones del menor desamparado con su núcleo afectivo de procedencia, debe proceder a la interpretación y aplicación, en el caso concreto y teniendo en cuenta las circunstancias particulares del niño y los criterios generales delimitadores del interés del menor del art. 2.2. LO 1/1996: a) la protección del derecho a la vida, supervivencia y desarrollo del menor y la satisfacción de sus necesidades básicas, tanto materiales, físicas y educativas como emocionales y afectivas ${ }^{188}$; b) la opinión del

${ }^{184}$ No obstante, algunas leyes autonómicas sí intentaron delimitar este concepto. Véanse así, el art. 4.1 de la Ley 3/2005, de atención y protección a la infancia y la adolescencia del País Vasco; art. 3.a) de la Ley 1272008, de 3 de julio, de protección integral de la infancia y la adolescencia de la Comunidad Valenciana; art. 4.2 de la Ley 8/2010, de 23 de diciembre, de garantía de derechos y atención al a infancia y la adolescencia de Cantabria; art. 4.a) de la Ley 14/2002, de 25 de julio, de promoción, atención y protección a la infancia de Castilla y León; art. 3.a) de la Ley 5/2014, de 9 de octubre, de protección social y jurídica de la infancia y la adolescencia; art. 5.4 de la Ley 14/2010, de 27 de mayo, de normas reguladoras de los derechos y las oportunidades en la infancia y la adolescencia de Cataluña; art. 38. a) de la Ley 3/2011, de 30 de junio, de apoyo a la familia y a la convivencia de Galicia.

185 Véase al respecto, Guilarte Martón-Calero (2014: 13-18).

186 Recomendación 17. BOCG, Senado, 545, 17 de noviembre de 2010, 51.

187 Sin embargo, al mismo tiempo y de un modo que puede resultar contradictorio, se recomendaba el "garantizar la valoración de cada supuesto con la aplicación de criterios flexibles que permitan tener en cuenta conceptos como la buena fe, la urgencia o el propio interés público, sin que en ningún caso quepa decir que los mismos están vacíos de contenido» (Recomendación 18. BOCG, Senado, 545, 17 de noviembre de 2010, 51).

188 El desarrollo integral del menor, en todas sus manifestaciones, abarca, de acuerdo con la $\mathrm{OB} 5, \$ 12$, el desarrollo físico, mental, espiritual, moral, psicológico y social del niño. La referencia a las necesidades tiene como referente el art. 1 (2) (b) Children Act 1989 que, al delimitar el concepto de bienestar del niño, hace mención a las necesidades educacionales, emocionales y psíquicas del menor. 
menor ${ }^{189}$; c) el derecho del menor a una vida en familia debiéndose otorgar prioridad a la familia de origen ${ }^{190}$, y d) el derecho al libre desarrollo de la personalidad del menor con mantenimiento de su identidad sin que pueda ser objeto, por esta causa, de discriminación alguna ${ }^{191}$.

Tales criterios deben ser ponderados, a su vez, con otros elementos generales a fin de hallar un adecuado equilibrio; elementos que deben ser valorados conjuntamente conforme a los principios de necesidad y proporcionalidad ${ }^{192}$, de forma que la medida que se adopte en el interés superior del menor no restrinja o limite más derechos que los que ampara: a) la edad y madurez del menor ${ }^{193}$; b) la necesidad de garantizar su igualdad; c) la incidencia del transcurso del tiempo en su desarrollo ${ }^{194}$; d) la necesidad de ofrecer soluciones estables y de minimizar los riesgos que un cambio en su estatus pudieran ocasionar en el desarrollo de su personalidad; e) la preparación del tránsito a la edad adulta e independiente, de acuerdo con sus capacidades y circunstancias personales; y a modo de cláusula de cierre, $\mathrm{y}$ «f) aquellos otros elementos de ponderación que, en el supuesto concreto, sean considerados pertinentes y respeten los derechos de los menores».

En verdad, no resulta en modo alguno objetable ninguno de estos criterios y elementos generales que podrán guiar la interpretación y aplicación del interés del menor al caso concreto, si bien resulta posible cuestionar hasta qué punto resultaba necesario explicitarlos cuando todos ellos podían ser reconducidos a una cláusula general que permitiera enlazar ese interés con los derechos fundamentales del menor, con su dignidad y con el libre desarrollo

Por tanto, bien puede decirse que el precepto resulta redundante. Pero, fíjese el lector la insistencia del legislador español para hacer hincapié en la dimensión física y material del bienestar del niño.

189 Véase OB 14, $\$ 53$ y 54. Cfr. art. 1 (2) (a) Children Act que hace referencia a los deseos y sentimientos del niño en función de su edad y entendimiento.

190 Véase OB 14, $\$ 58$ a 70.

191 Véase OB 14, $\$ 55$ a 57.

192 De acuerdo con la OB $14, \$ 80$, «cabe destacar que la evaluación básica del interés superior es una valoración general de todos los elementos que guarden relación con el interés superior del niño, en la que la importancia de cada elemento se pondera en función de los otros. No todos los elementos serán pertinentes en todos los casos, y los diversos elementos pueden utilizarse de diferentes maneras en los distintos casos. El contenido de cada elemento variará necesariamente de un niño a otro y de un caso a otro, dependiendo del tipo de decisión y las circunstancias concretas, al igual que la importancia de cada elemento en la evaluación general».

193 Véase OB 14, $\$ 83$

194 Véase OB 14, $\$ 84$. 
de su personalidad (arg. ex art. $10 \mathrm{CE})^{195}$. De otra parte, a pesar de los buenos propósitos, el interés del menor sigue siendo un concepto jurídico indeterminado de perfiles vagos, en la medida en que en él van a seguir estando presentes elementos no del todo racionales y, fundamentalmente, porque en su valoración, evaluación y ponderación pueden utilizarse otros criterios distintos a los expresa y legalmente reseñados, como evidencia la redacción del apartado f) del art. 2.2, párrafo segundo, de la LO 1/1996, tal y como se ha indicado, aunque eso sí, puedan rechazarse aquellos que no resulten atentos con aquellos derechos y valores constitucionalmente protegidos en la cláusula igualmente general del art. $10 \mathrm{CE}$.

\section{LA NECESIDAD Y PROPORCIONALIDAD EN LA MOTIVACIÓN EN INTERÉS DEL MENOR DE LAS RESOLUCIONES QUE ACUERDEN UNA RESTRICCIÓN O LIMITACIÓN DE LAS RELACIONES DEL MENOR CON SU NÚCLEO AFECTIVO DE ORIGEN}

No obstante, tal y como expresa el apartado 3 del art. 2 LO 1/1996, en esa motivación en el interés del menor, la entidad pública (y, en su caso, el juez, al fiscalizar la actuación administrativa) ha de justificar que, precisamente, la medida que adopta, limitando o suspendiendo las relaciones entre el menor desamparado y su familia de origen, resulta necesaria para atender a ese interés y proporcionada, tal y como así entendía, aun antes de la reforma de 2015, nuestro Tribunal Constitucional ${ }^{196}$, que a la hora de enjuiciar la obligada motivación de las resoluciones judiciales cuando el interés del menor estuviera implicado, consideraba que la fundamentación debía entenderse lesiva desde la perspectiva constitucional desde el momento en que existía una absoluta falta de ponderación del citado principio ${ }^{197}$. En definitiva, estimaba que «el interés superior del niño obliga a la autoridad judicial a un juicio de ponderación que debe constar expresamente en la resolución judicial, identifi-

195 En cierta medida, pues, el interés del menor se relaciona, como así puso de manifestó el Tribunal Supremo, con anterioridad a la reforma, con «el desenvolvimiento libre e integral de la personalidad del menor y la supremacía de todo lo que le beneficie, más allá de las preferencias personales de sus padres, tutores, guardadores o administraciones públicas, en orden a su desarrollo físico, ético y cultural; bien con su salud y su bienestar psíquico y su afectividad, junto a otros aspectos de tipo material; bien, simplemente con la protección de sus derechos fundamentales» [(STS 20.7.2015 (RJ 2015, 2786). Igualmente, véase STS 2.12.2015 (RJ 2016, 117)].

196 STC 127/2013, de 3 de junio (RTC 2013, 127).

197 SSTC 138/2014, de 8 de septiembre (RTC 2014, 138) y 65/2016, de 11 de abril (RTC 2016, 65). 
cando los bienes y derechos en juego que pugnan de cada lado, a fin de poder calibrar la necesidad y proporcionalidad de la medida adoptada ${ }^{198}$.

Pues bien, para apreciar la necesidad, conforme a una doctrina constante del TEDH ${ }^{199}$, se ha de examinar, a la vista del conjunto de las circunstancias, si los motivos invocados para justificarlas son pertinentes, suficientes y proporcionados para autorizar la intromisión en el ámbito de los derechos reconocidos y garantizados por el art. $8 \mathrm{CEDH}$, teniendo en cuenta la obligación que tiene el Estado de permitir el mantenimiento del vínculo entre el menor y su núcleo afectivo de origen ${ }^{200}$.

En su entendimiento, "el art. 8 exige que las autoridades internas guarden un equilibrio justo ${ }^{201}$ entre los intereses del hijo y los de sus padres y que, al hacerlo, concedan una particular importancia al interés superior del menor, el cual, según su naturaleza y gravedad, prevalece sobre el de los padres». En particular, considera que no cabe autorizar que un progenitor adopte medidas perjudiciales para la salud $\mathrm{d}^{202} \mathrm{y} / \mathrm{o}$ el desarrollo del niño ${ }^{203}$, por lo que una deci-

198 STC 176/2008, de 22 de diciembre (RTC 2008, 176). ATC 47/2009, de 13 de febrero (RTC 2009, 47 Auto). Véanse asimismo, SSTC 127/2013, de 3 de junio (RTC 2013, 127); 138/2014, de 8 de septiembre (RTC 2014, 138) y 16/2016, de 1 de febrero (RTC 2016, 16).

199 A título ilustrativo, véanse SSTEDH 16.7.2015 — asunto Akinnibosun contra Italia- (JUR 2015, 185807); 27.1.2015 —asunto Paradiso y Campanelli contra Italia- (TEDH 2015, 17).

200 Véase así, STEDH 12.7.2001 —asunto K. y T. contra Finlandia- (TEDH 2001, 467). Igualmente, véase STEDH 26.11.2009 —asunto Vautier contra Francia(TEDH 2009, 126). Véase asimismo, por ejemplo, SSTEDH 12.7.2001 —asunto K. y T. contra Finlandia- (TEDH 2001, 467) y 8.1.2013 —asunto A.K. y L. contra Croacia- (TEDH 2013, 5).

201 STEDH 16.7.2015 — asunto Akinnibosun contra Italia— (JUR 2015, 185807).

202 Véanse por ejemplo, SSTDEH 10.2.2011 —asunto Tsikakis contra Alemania(JUR 2011, 37824); 1.8.2013 —asunto Dmitriy contra Rusia- (JUR 2013, 269763); 4.9.2014 — asunto Drenk contra República Checa- (JUR 2014, 223068); 28.4.2016 —asunto Cincimino contra Italia- (JUR 2016, 85031).

203 Entre otras, véase SSTEDH 13.7.2000 — asunto Elsholz contra Alemania- (TEDH 2000, 152); 5.12.2002 —asunto Hoppe contra Alemania- (TEDH 2002, 72); 8.7.2003 —asunto Sommerfeld contra Alemania- (JUR 2003, 162887); 6.12.2007 — caso Maumousseau contra Francia- (TEDH 2010, 82); 26.5.2009 —asunto Amanalachioai contra Rumanía- (TEDH 2009, 59); 8.7.2010 —asunto Döring contra Alemania- (TEDH 2007, 88); 18.10.2011 —asunto Lyubenova contra Bulgaria(TEDH 2011, 83); 27.9.2011 —asunto M. y C. contra Rumanía- (TEDH 2011, 75); 8.1.2013 —asunto Qama v. contra Albania- (TEDH, 2013, 3); 21.1.2014 — asunto Zhou contra Italia- (JUR 2014, 15444); 27.5.2014 —asunto Buchs contra 
sión de no admitir las visitas de un padre con su hijo ante la sospecha de abusos sexuales $^{204}$ o cuando se ha mostrado particularmente indigno ${ }^{205}$, no supondría una injerencia indebida en la vida privada y familiar de ese progenitor ${ }^{206}$. En definitiva, "un niño debe estar en contacto con ambos progenitores hasta el punto en que esto esté de acuerdo con los intereses del niño» ${ }^{207}$, por lo que la restricción de las relaciones o la separación familiar solo han de reputarse conformes al art. $8 \mathrm{CEDH}$ cuando estén justificadas por una exigencia primaria de respeto al interés del menor ${ }^{208}$. Por ejemplo, no resultaría posible admitir que el menor pudiera quedar expuesto a una situación de violencia o maltrato físico ${ }^{209}$ o psicológico ${ }^{210}$ o a abusos sexuales ${ }^{211}$ ni habría de permitirse que las relaciones

Suiza- (JUR 2014, 161780); 4.9.2014 —asunto Drenk contra República Checa(JUR 2014, 223068). 16.7.2015 —asunto Akinnibosun contra Italia- (JUR 2015, 185807); 28.4.2016 — asunto Cincimino contra Italia- (JUR 2016, 85031).

${ }^{204}$ Véase STEDH 24.2.2009 —asunto Errico contra Italia- (TEDH 2009, 26). Cfr. STEDH 27.9.2011 —asunto M. y C. contra Rumanía- (TEDH 2011, 75). Ahora bien, debe advertirse que, aun cuando ante una sospecha de abusos sexuales quepa suspender las relaciones del progenitor hacia su hijo, por lo que la medida puede reputarse justificada, al ser necesaria y proporcionada, en cambio, el retraso del procedimiento penal del que luego resulta la absolución de ese padre sin que se adopten otras medidas puede conducir a una vulneración del art. 8.1 CEDH [STEDH 24.2.2009 —asunto Errico contra Italia- (TEDH 2009, 26)]. Respecto a un caso en que se suspenden las visitas de los abuelos paternos a su nieta por las sospechas de abusos sexuales del progenitor luego no acreditados y en el que también se aprecia violación del art. 8 CEDH, véase STEDH 20.1.2015 — asunto Manuello y Nevi contra Italia- (TEDH 2015, 16).

205 SSTEDH 21.1.2014 —asunto Zhou contra Italia— (JUR 2014, 15444); 16.7.2015 —asunto Akinnibosun contra Italia- (JUR 2015, 185807).

206 STEDH 8.7.2010 — asunto Döring contra Alemania- (TEDH 2010, 82).

207 SSTEDH 5.12.2002 —asunto Hoppe contra Alemania- (TEDH 2002, 72); 16.9.2014 — asunto P.F. contra Polonia- (JUR 2014, 227328).

208 STEDH 16.7.2015 — asunto Akinnibosun contra Italia — (JUR 2015, 185807).

209 Véase SAP Castellón 27.2.2015 (JUR 2015, 124166) que considera inviable la reinserción familiar de una niña de dos años en atención a la tolerancia de la progenitora hacia ese maltrato ejecutado por el padre y ante la ausencia de garantías de la abuela paterna para impedir injerencias de los padres en el ejercicio del cuidado de la menor. Cfr. esta resolución con la SAP Girona 20.1.2014 (JUR 2014, 54318) que acuerda ampliar el régimen de visitas de una madre a sus hijas acogidas en función de la vinculación afectiva entre ellas.

210 Véase STEDH 22.10.2015 — asunto Jovanovic contra Suecia- (JUR 2015, 246772).

211 STEDH 27.1.2015 — asunto Paradiso y Campanelli contra Italia- (TEDH 2015, 17). Asimismo, véase STEDH 16.9.2014 — asunto P.F. contra Polonia- (JUR 2014, 
tuvieran efectos perniciosos para el menor hasta el punto de requerir tratamiento médico ${ }^{212}$. Pero, a su juicio, éstas son medidas de último recurso que deben responder al propósito de proteger al niño frente a una amenaza inmediata ${ }^{213}$.

Igualmente ha entendido que el hecho de que un niño pueda ser acogido en un marco más propicio para su educación ${ }^{214}$ no es motivo bastante para alejarlo de su familia, ni para restringir las relaciones familiares. Unas condiciones de vida insatisfactorias o las privaciones materiales ${ }^{215}$ de la familia no son razones necesarias para autorizar la injerencia en la esfera de los derechos del art. $8 \mathrm{CEDH}$, salvo que estas circunstancias estén unidas a otros elementos, tales como, el estado psíquico de los progenitores o su incapacidad afectiva, educativa y pedagógica ${ }^{216}$. Incluso, el mero hecho de burlar la ley de adopción nacional no es justificación bastante para propiciar la separación familiar ${ }^{217}$. Como tampoco lo es, la «indiferencia emocional del menor» hacia su progenitora o las tensas relaciones durante las visitas como causa de una eventual perturbación de la estabilidad y desarrollo de una menor ${ }^{218}$.

A juicio del TEDH, la adecuación de una medida también puede evaluarse, entre otros criterios, por la rapidez de su ejecución ${ }^{219}$. Sin embargo,

227328). Por eso mismo no existirá, a juicio del TEDH, vulneración del art. 3.1 $\mathrm{CEDH}$ en relación con el art. $8 \mathrm{CEDH}$ en el caso de que las autoridades nacionales no hubieran procedido a separar a un menor de su entorno familiar ante una sospecha de abusos sexuales cuando hubiese prueba suficiente de dichos abusos [STEDH 15.11.2011 —asunto M.P. y otros contra Bulgaria- (TEDH 2011, 99)].

212 Véanse STEDH 20.1.2011 — asunto Rytchenko contra Rusia- (JUR 2011, 14350).

213 Véanse STEDH 27.1.2015 — asunto Paradiso y Campanelli contra Italia— (TEDH 2015, 17).

214 Véanse STEDH 26.5.2009 —asunto Amanalachioai contra Rumanía- (TEDH 2009, 59).

${ }^{215} \mathrm{Ni}$ mucho menos en la situación de indigencia de los progenitores. Véase STEDH 18.6.2013 — asunto R.M.S. contra España (TEDH 2013, 60).

216 Véanse STEDH 26.10.2006 —asunto Wallová y Walla contra República Checa(JUR 2007, 252587).

217 Véanse STEDH 27.1.2015 —asunto Paradiso y Campanelli contra Italia— (TEDH 2015, 17).

218 Véanse STEDH 18.6.2013 —asunto R.M.S. contra España (TEDH 2013, 60). Véase también las consideraciones que realiza la STSJ Cataluña 4.5.2015 (RJ 2015, 3760) sobre la insuficiencia de la referencia a las habilidades emocionales y pedagógicas de una madre para fundar el desamparo de su hijo menor.

219 Véanse entre otras, SSTEDH 13.10.2009 —asunto Costreie contra Rumanía (TEDH 2009, 105); 22.9.2009 —asunto Stocklak contra Polonia- (TEDH 2009, 96); 2.2.2010 — asunto Dabrowska contra Polonia- (TEDH 2010, 21). 12.4.2011 —asunto Gluhakovic contra Croacia_ (JUR 2011, 113684); 3.11.2011 —asunto 
a su entender, la adaptación del menor a un nuevo entorno familiar no resulta bastante para justificar la ruptura definitiva de las relaciones, aunque sí la suspensión temporal ${ }^{220}$, puesto que también resulta obligado facilitar la reanudación de la vida familiar, ya que el art. $8 \mathrm{CEDH}$ comprende también la adopción de las medidas preparatorias para alcanzar ese resultado ${ }^{221}$. Y es que «el respeto efectivo por la vida familiar requiere que las relaciones futuras entre padre y un hijo no pueden verse determinadas por el mero transcurrir del tiempo» ${ }^{222}$. De otra parte, a pesar de que las autoridades nacionales gozan de una amplia libertad para valorar la necesidad, en especial cuando

Kuscuoglu contra Turquía- (TEDH 2011, 91); 11.12.2012 —asunto Ball contra Andorra- (TEDH 2012, 118); 20.1.2015 —asunto Manuello y Nevi contra Italia- (TEDH 2015, 16); 2.4.2015 —asunto Ribic contra Croacia- (JUR 2015, 97675); 16.7.2015 —asunto Akinnibosun contra Italia- (JUR 2015, 185807); 17.11.2015 —asunto Bondavalli contra Italia- (JUR 2015, 272074). De ahí que también haya entendido que el retraso de un año y nueve meses para resolver sobre la guarda y custodia de un menor que durante ese tiempo estuvo en acogimiento supone una vulneración del art. 6.1 CEDH, pues, atendidas las circunstancias del caso, la duración del procedimento resulta excesiva y no responde a la exigencia del plazo razonable al que hace referencia dicho precepto [STEDH 26.11.2009 —asunto Abduvalieva contra Alemania- (TEDH 2009, 128)]. Y es que, con carácter general, ha considerado que los asuntos relativos a la autoridad parental y al derecho de visita deben ser tratatados con una particular celeridad [STEDH 10.2.2011 —asunto Tsikakis contra Alemania- (JUR 2011, 37824)]. Asimismo, véanse STEDH 28.6.2012 —asunto X. contra Eslovenia- (JUR 2012, 216896); 2.4.2015 —asunto Ribic contra Croacia- (JUR 2015, 97675).

Igualmente, véase STC 16/2016, de 1 de febrero (RTC 2016, 16).

220 STEDH 26.5.2009 —asunto Amanalachioai contra Rumanía-(TEDH 2009, 59).

221 STEDH 26.5.2009 —asunto Amanalachioai contra Rumanía-(TEDH 2009, 59). Véanse igualmente, STEDH 22.9.2009 —asunto Stocklak contra Polonia(TEDH 2009, 96); 20.12. 2011 —asunto Prodelalovà contra República Checa(TEDH 2011, 111); 18.6.2013 —asunto RMS contra España- (TEDH 2013, 60). 18.10.2011 —asunto Lyubenova contra Bulgaria- (TEDH 2011, 83); 16.7.2015 —asunto Mamchur contra Ucrania_ (JUR 2015, 185811). Igualmente, para los supuestos en que, apreciada la inexistencia de desamparo, se entiende que el interés del menor aconseja mantener el acogimiento provisionalmente estableciéndose un régimen de visitas progresivo, véanse SSTSJ Cataluña 12.3.2015 (RJ 2015, 2580) y 4.5.2015 (RJ 2015, 3760).

222 STEDH 2.2.2010 — asunto Dabrowska contra Polonia- (TEDH 2010, 21). Igualmente, véanse SSTEDH 18.10.2011 —asunto Lyubenova contra Bulgaria— (TEDH 2011, 83); 22.4.2010 —asunto Macready contra República Checa- (JUR 2010, 121726). 
existe una urgencia, se habrá de evaluar especialmente si existen o no otras soluciones distintas antes de ejecutar una medida que puede resultar irremediable ${ }^{223}$ y si existen circunstancias tales que justifiquen la ruptura de las relaciones familiares ${ }^{224}$.

En definitiva, solo ante razones de mucho peso ${ }^{225} \mathrm{y}$, por tanto, importantes $^{226}$, relevantes y suficientes ${ }^{227}$, cabe admitir esa injerencia pública en la esfera de los derechos que pretenden garantizar la relación personal del individuo ${ }^{228}$. Por tanto, «el interés del menor impone que solo en circunstancias excepcio-

223 STEDH 27.1.2015 — asunto Paradiso y Campanelli contra Italia- (TEDH 2015, 17).

224 STEDH 16.7.2015 —asunto Akinnibosun contra Italia- (JUR 2015, 185807).

225 STEDH 18.6.2013 —asunto RMS contra España- (TEDH 2013, 60).

${ }^{226}$ En aplicación del art. 160 CC, el Tribunal Supremo entiende (SSTS 19.10.1992 —RJ 1992,8083-; 22.5.1993 - RJ 1993, 3977-; 21.11.2005 — RJ 2005, 7734-; 11.2.2011 - RJ 2011, 2311-) que este derecho de visita puede verse limitado o suspendido si concurren graves circunstancias que así lo aconsejen, por lo que debe ceder en caso de "peligro concreto y real para salud física, psíquica o moral del hijo» que habrá de acreditarse. Por tanto, solo ante casos muy motivados y extremos cabe suspender el régimen de visitas (STS 16.7.2015 — RJ 2015, 2782-). En esa misma línea, el Tribunal Constitucional (S. 176/2008, de 22 de diciembre -RTC 2008, 176-) considera que el riesgo para el menor que pudiera justificar la restricción de las visitas o su suspensión puede consistir en una alteración efectiva de la personalidad del hijo, "merced a un comportamiento socialmente indebido de su progenitor, bien sea por la negatividad de los valores sociales o afectivos que este le transmite durante el tiempo en que se comunican, bien por sufrir el menor de manera directa los efectos de actos violentos, inhumanos o degradantes a su dignidad ocasionados por el padre o la madre, o que de manera persistente alteran o perturban su psique». Incluso, llega a admitir como causa justificadora, cualquier otra perturbación de la personalidad del hijo, «incluso si se debieran a circunstancias incontrolables para el progenitor causante (depresiones o problemas mentales de diversa índole)».

227 Véanse por ejemplo, SSTEDH 20.1.2011 —asunto Rytchenko contra Rusia- (JUR 2011, 14350); 10.2.2011 — asunto Tsikakis contra Alemania- (JUR 2011, 37824); 1.8.2013 —asunto Dmitriy Ryabov contra Rusia- (JUR 2013, 269763); 27.5.2014 — asunto Buchs contra Suiza- (JUR 2014 161870); 2.4.2015 —asunto Ribic contra Croacia- (JUR 2015, 97675); 22.10.2015 — asunto Jovanovic contra Suecia(JUR 2015, 246772). 16.7.2015 —asunto Mamchur contra Ucrania- (JUR 2015, 185811).

228 A consideraciones suficientemente sólidas e importantes en el interés del menor hace referencia la STEDH 27.9.2011 — asunto M. y C. contra Rumanía- (TEDH 2011, 75). 
nales pueden llevar a un ruptura del vínculo familiar y que sea haga lo posible para mantener las relaciones personales ${ }^{229}$.

Pero además, esa decisión habrá de tener en cuenta no solo los derechos del menor, sino también los de los demás interesados, tales como su libertad ideológica o religiosa o su derecho a la libertad de orientación sexual ${ }^{230}$, por lo que únicamente cabría restringir o suspender las relaciones del menor con sus progenitores, abuelos, parientes y otros allegados en el supuesto de que resultara acreditado que esa ideología o esa religión ${ }^{231}$ repercuten negativamente y constituyen un peligro para la salud o para la integridad física o moral del menor e inciden perjudicialmente en el desarrollo de su personalidad.

En suma, en ese proceso de evaluación y de concreción del interés del menor, habrá de valorarse también que la decisión que se adopte en ese interés no restrinja o limite más derechos que los que ampara, como así ordena ahora el art. 2.3 LO 1/1996. Y, en este orden de cosas, siempre habrá de tenerse presente, sin que ello suponga abogar en pro del hoy al parecer denostado biologismo ${ }^{232}$, que el interés del menor no puede erigirse en coartada de una

229 STEDH 28.4.2016 —asunto Cincimino contra Italia- (JUR 2016, 85031).

230 STC 176/2008, de 22 de diciembre (RTC 2008, 176) y STDEH 30.11.2010 —asunto P.V. contra España- (TEDH 2010, 112).

231 Véase STEDH 12.2.2013 —asunto Vojnity contra Hungría- (TEDH 2013, 18). De ahí que si no se acredita que las creencias o la ideología de un progenitor son efectivamente peligrosas o perjudiciales para el desarrollo personal de sus hijos no debe haber lugar a una restricción severa de las relaciones personales entre ellos, pues una medida semejante no se revelaría ni como necesaria y resultaría desproporcionada al resultar afectada la libertad ideológica y de creencias del propio padre [STC 141/2000, de 29 de mayo (RTC 2000, 141)].

232 En efecto, una lectura de algunos de los trabajos previos que dieron lugar a esta reforma parecen dar la impresión de que, en verdad lo que se pretendía, con esta revisión, era rebajar la prioridad o el nivel de valoración que había de darse a los intereses de la propia familia de origen del niño y ensalzar la importancia del interés del menor sobre el que habría de gravitar la nueva regulación. Así, en el Senado, en el seno de la Comisión Especial para el Estudio de la Problemática de la Adopción Nacional y Otros Temas Afines, se denunciaba cómo claramente, en demasiadas ocasiones, resultaba posible detectar, tanto en la actuación de las entidades públicas como, sobre todo en la judicatura, «un excesivo biologismo, entendido como una preterición del interés superior del menor frente a otros intereses de los padres biológicos, que van más allá de la admitida y recomendable pretensión de mantener al menor en el medio familiar de origen cuando ello sea posible» (Véase BOCG, Senado, núm. 545, 17 de noviembre de 2010, 45). Esto es, todo apunta a que en el planteamiento de esta Comisión y en el de alguno de sus comparecientes se mostraba un cierto recelo hacia la atención prestada por los operadores jurídicos a la familia biológica del menor que era percibida 
decisión arbitraria no respetuosa con los derechos fundamentales de los afectados por una resolución de la entidad pública.

Aunque siempre será una tarea enormemente ardua alcanzar en esta materia una deseable conciliación de los intereses en conflicto y aun cuando resulte necesario otorgar prevalencia al interés del menor frente a cualquier otro que pueda estar en juego ${ }^{233}$, tal y como así evidencia claramente el art. 2 LO 1/1996 y resulte oportuno en aras de ese interés eliminar o, al menos, amortiguar, posibles actuaciones obstaculizadoras por parte de la familia de origen del menor, no cabrá desconocer los derechos fundamentales de los interesados ni sus garantías procesales. Por este motivo, no está de más recordar, como tuvo la oportunidad de afirmar nuestro Tribunal Constitucional ${ }^{234}$, aun admitiendo que el interés del menor es relevante, que el de sus progenitores, aun siendo de menor rango, «no por ello resulta desdeñable», por lo que existirá vulneración del art. $24 \mathrm{CE}$ cuando en la resolución correspondiente falte el juicio de ponderación pertinente entre los intereses de los afectados por una decisión que constriña las relaciones entre el menor y su núcleo afectivo de procedencia.

\section{BIBLIOGRAFÍA}

Bianca, C. M. (2002). Art. 1. En C. M. Bianca y L. Rossi Carleo. (coords.) Commentario alla L. 28 marzo 2001, n. 149.; Le nuove leggi civili comentate (IV, V).

Cabello Mallol, V. (2016). Principales novedades incorporadas a las leyes de reforma del sistema de protección a la infancia y a la adolescencia: luces y sombras. En V. Cabedo y I. Ravetllat. Comentarios sobre las leyes de reforma del sistema de protección a la infancia y la adolescencia. Valencia: Tirant lo Blanch.

Colás Escandón, A. M. (2015). El régimen de relaciones personales entre abuelos y nietos fijado judicialmente, con especial referencia a su extensión (a propósito de la STC, Sala 2a, no 138/2014, de 8 de septiembre). Derecho Privado y Constitución, 29, $133-185$.

por algunos como uno de los obstáculos que impedían una adecuada tutela jurídica, por lo que era necesario vencer tales rémoras en orden a la mejor protección de los intereses del niño.

233 Tal y como así resulta del mismo art. 3.1 de la Convención de los Derechos del Niño.

234 SSTC 141/2000, de 29 de mayo (RTC 2000, 141); 124/2002, de 20 de mayo (RTC 2002, 124); 144/2003, de 14 de julio (RTC 2003, 144); 71/2004, de 19 de abril (RTC 2004, 71); 11/2008, de 21 de enero (RTC 2008, 11) y 16/2016, de 1 de febrero (RTC 2016, 16). 
Comité de los Derechos del Niño (2009). Observación General no 12 (2009). El derecho del niño a ser escuchado. $51^{\circ}$ período de sesiones. Ginebra, 25 de mayo a 12 de junio de 2009. CRC/C/GC/12. 20 de julio de 2009.

- (2010). Examen de los informes presentados por los Estados partes en virtud del artículo 44 de la Convención. Entorno familiar y modalidades alternativa de cuidado (artículos 5,18 —párrafos 1 y 2- 9 a 11,19 a 21, 25, 27 —párrafo 4-y 39 de la Convención, $55^{\circ}$ período de sesiones (CRC/C/ESP/CO/3-4).

- (2013). Observación general 14 (2013) sobre el derecho del niño a que su interés sea una consideración primordial (artículo 3, párrafo 1), 29 de mayo de 2013 (CRC/C/ $\mathrm{GC} / 14)$.

De la Iglesia Monje, M. I. (2016). Acogimiento residencial, suspensión del régimen de visitas del menor y su interés supremo. Revista Crítica de Derecho Inmobiliario, 92, (753), 435-448.

Defensor del Pueblo (2014). Estudio sobre la escucha y el interés del menor. Revisión judicial de medidas de protección y procesos de familia. Madrid: Defensor del Pueblo.

Díaz Martínez, A. (2014). La tutela judicial efectiva en los procedimientos de oposición a las resoluciones sobre protección de menores. Revista Aranzadi Civil-Mercantil, 2 (5), 37-52.

- (2016). Comentario a los artículos 81, 82, 83, 84, 89. 90 y 95 del Código Civil. En R. Bercovitz (dir.). Las modificaciones al Código Civil del año 2015. Valencia: Tirant lo Blanch.

Díez García, H. (2010). La protección de menores en conflicto social, con conductas disruptivas, inadaptadas o antisociales (análisis de la atención a la peligrosidad social en las leyes autonómicas de protección de menores desde el prisma constitucional). Derecho Privado y Constitución, 24, 197-289.

- (2013). Comentarios a los arts. 154 a 198 CC. En R. BERCOVITZ. Comentarios al Código Civil, II. Valencia: Tirant lo Blanch.

Egea Fernández, J. (1995). La doctrina constitucional sobre la oposición judicial a la declaración de desamparo hecha por la entidad pública. Derecho Privado y Constitución, 5, 253-288.

Ferrer Riba, J. (2010). Principles and prospects for a European System of Child Protection. Indret, 2, 2-31.

Fiscalía General del Estado (2013). Memoria elevada al Gobierno de S. M. por el Fiscal General del Estado. Madrid: Centro de Estudios Jurídicos, Ministerio de Justicia.

Guilarte Martín-Calero, C. (2014). La concreción del interés del menor en la Jurisprudencia del Tribunal Supremo. Valencia: Tirant lo Blanch.

- (2016). El interés superior del niño: la nueva configuración del artículo 2 de la Ley Orgánica, de 15 de enero, de protección jurídica del menor. En V. Cabedo y I. Ravetllat. Comentarios sobre las leyes de reforma del sistema de protección a la infancia y la adolescencia. Valencia: Tirant lo Blanch.

Marín López, M. J. (2005). Tutela judicial efectiva y audiencia del menor en los procesos judiciales que le afecten. Derecho Privado y Constitución, 19, 165-223. 
- (2009). La audiencia del menor en los procesos matrimoniales tras la Ley 15/2005, de 8 de julio, que modifica el régimen de separación y divorcio. Derecho Privado y Constitución, 23, 249-283.

ONU (2010). Directrices sobre sobre las modalidades alternativas de cuidado de los niños, Resolución de la Asamblea General, Sexagésimo cuarto período de sesiones, 24 de febrero de 2010 (A/RES/64/142).

Pérez Álvarez, M.A. (2011). Comentario al art. 172 y a los arts. 175 a 177 CC. En A. Cañizares et al. (dir.). Código Civil comentado, I. Cizur Menor: Thomson-Reuters/ Aranzadi.

Pérez Conesa, C. (2015). Doctrina jurisprudencial a partir de la STS de 18 de junio de 2014: la entidad pública es competente para suspender el régimen de visitas de menores bajo su tutela y en acogimiento residencial respecto de sus padres biológicos. Revista Aranzadi Civil-Mercantil, 2 (9), 123-126.

Rivero Hernández, F. (1997). El derecho de visita. Barcelona: Bosch.

Ruiz-Rico Morón, J. (2016). Últimas reformas de las instituciones privadas de protección de menores y la filiación por la Ley 26/2015, de modificación del sistema de protección a la infancia y la adolescencia. Revista Doctrinal Aranzadi Civil-Mercantil, 3, 47-73.

Sabater Bayle, E. (2016). La adopción abierta. En V. Cabedo y I. Ravetllat. Comentarios sobre las leyes de reforma del sistema de protección a la infancia y la adolescencia. Valencia: Tirant lo Blanch.

Salanova Villanueva, M. (2003). Tutela y protección de menores en la Jurisprudencia del Tribunal Europeo de Derechos Humanos. Aranzadi Civil: Revista Quincenal, 1, 4. 